\title{
Cultural Resource Investigations for a Multipurpose Haul Road on the Idaho National Laboratory
}

Brenda R. Pace Cameron Brizzee Hollie Gilbert Clayton Marler Julie Braun Williams Dino Lowrey

August 2010 Idaho National Laboratory

The INL is a U.S. Department of Energy National Laboratory operated by Battelle Energy Alliance 


\section{DISCLAIMER}

This information was prepared as an account of work sponsored by an agency of the U.S. Government. Neither the U.S. Government nor any

agency thereof, nor any of their employees, makes any warranty, expressed or implied, or assumes any legal liability or responsibility for the accuracy, completeness, or usefulness, of any information, apparatus, product, or process disclosed, or represents that its use would not infringe privately owned rights. References herein to any specific commercial product, process, or service by trade name, trade mark, manufacturer, or otherwise, does not necessarily constitute or imply its endorsement, recommendation, or favoring by the U.S. Government or any agency thereof. The views and opinions of authors expressed herein do not necessarily state or reflect those of the U.S. Government or any agency thereof. 


\title{
Cultural Resource Investigations for a Multipurpose Haul Road on the Idaho National Laboratory
}

\author{
Brenda R. Pace \\ Cameron Brizzee \\ Hollie Gilbert \\ Clayton Marler \\ Julie Braun Williams \\ Dino Lowrey
}

August 2010

\begin{abstract}
Idaho National Laboratory Cultural Resource Management Idaho Falls, Idaho 83415
\end{abstract}

http://www.inl.gov

Prepared for the

U.S. Department of Energy

Office of Nuclear Energy

Under DOE Idaho Operations Office

Contract DE-AC07-05ID14517 
INTENTIONALLY BLANK 


\begin{abstract}
The U. S. Department of Energy, Idaho Operations Office is considering options for construction of a multipurpose haul road to transport materials and wastes between the Materials and Fuels Complex (MFC) and other Idaho National Laboratory (INL) Site facilities. The proposed road will be closed to the public and designed for limited year-round use. Two primary options are under consideration: a new route south of the existing T-25 power line road and an upgrade to road T-24. In the Spring of 2010, archaeological field surveys and initial coordination and field reconnaissance with representatives from the Shoshone-Bannock Tribes were completed to identify any resources that may be adversely affected by the proposed road construction and to develop recommendations to protect any listed or eligible for listing on the National Register of Historic Places. The investigations showed that 24 archaeological resources and one historic marker are located in the area of potential effects for road construction and operation south of the T-25 powerline road and 27 archaeological resources are located in the area of potential effects for road construction and operation along road T-24. Generalized tribal concerns regarding protection of natural resources were also documented in both road corridors. This report outlines recommendations for additional investigations and protective measures that can be implemented to minimize adverse impacts to the identified resources.
\end{abstract}


INTENTIONALLY BLANK 


\section{Acknowledgements}

These cultural resource investigations were accomplished by a diverse team from the Idaho National Laboratory's Cultural Resource Management Office. Julie Braun Williams is the cultural resources team lead. Archaeological surveys were coordinated by Brenda Pace with assistance from Cameron Brizzee, Julie Braun Williams, Clayton Marler, Dino Lowrey, and Hollie Gilbert. Clayton Marler also escorted tribal representatives Caroline Smith, LaRae Buckskin, and Anthony Bagley from the Shoshone-Bannock Tribe's Heritage Tribal Office to the project area. Brenda Pace prepared the report with editorial and formatting assistance from Cheryl Swank. The final document is also enhanced by maps created by Cameron Brizzee. 
INTENTIONALLY BLANK 


\section{CONTENTS}

Abstract iii

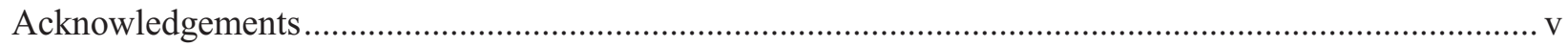

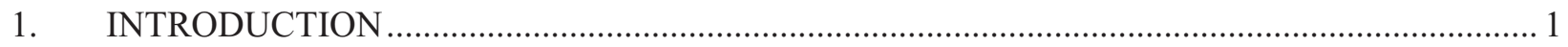

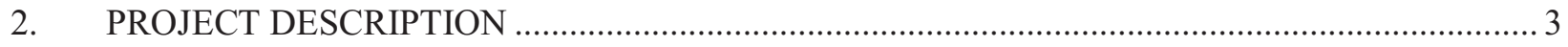

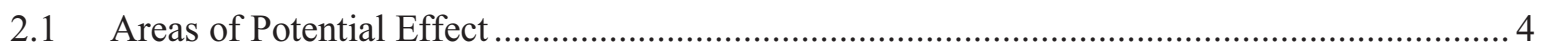

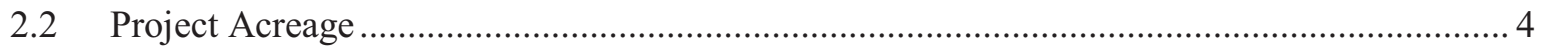

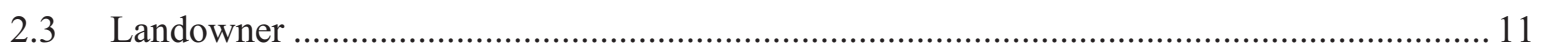

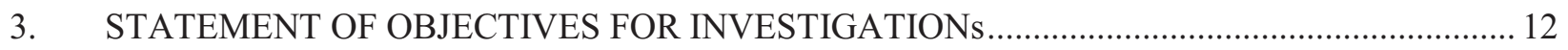

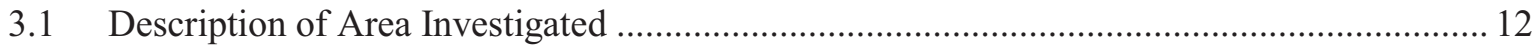

3.2 Amount and Types of Information Collected ............................................................... 12

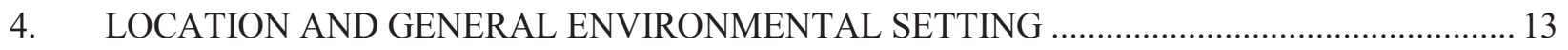

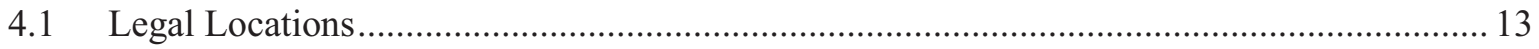

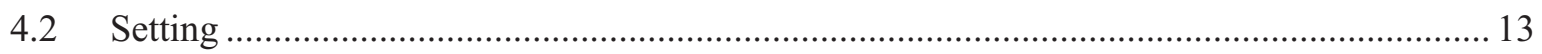

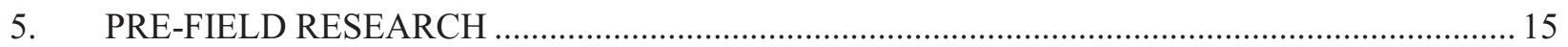

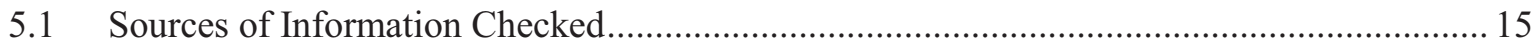

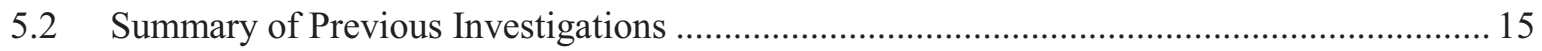

5.3 Evaluation of Previous Investigations................................................................................ 19

6. EXPECTED HISTORIC AND PREHISTORIC LAND USE AND SITE DENSITY …................2 20

6.1 Known or Expected Resources ......................................................................................... 20

6.2 Known or Expected Themes, Time Periods, and INL Contexts ......................................... 23

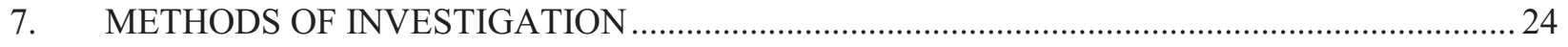

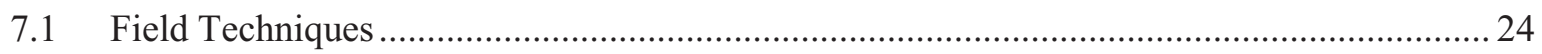

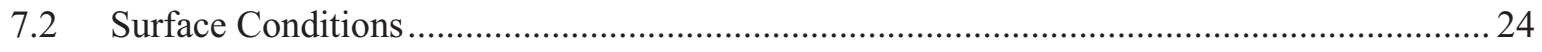

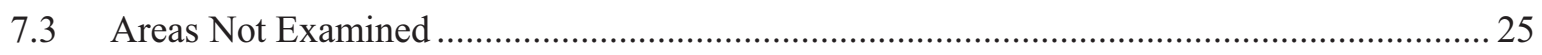

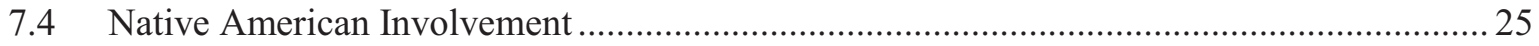

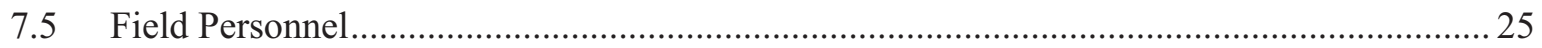

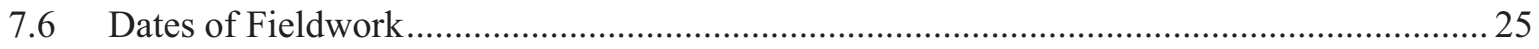

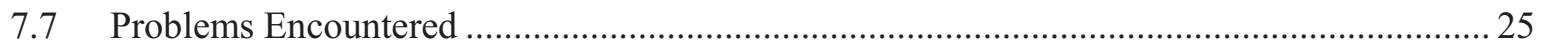

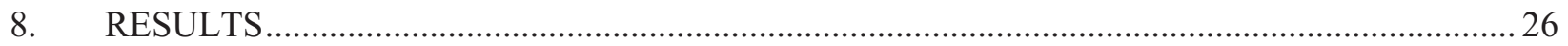

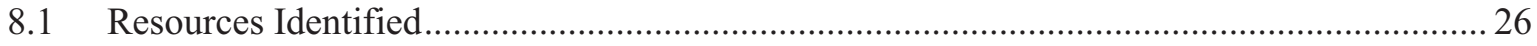

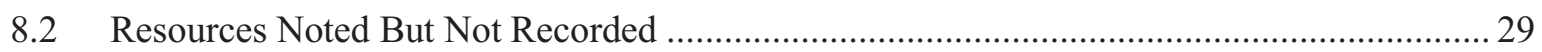

8.3 Summary of Important Characteristics of Identified Resources ......................................... 30

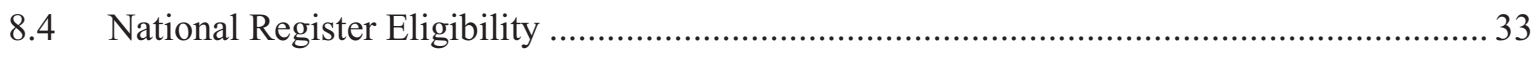

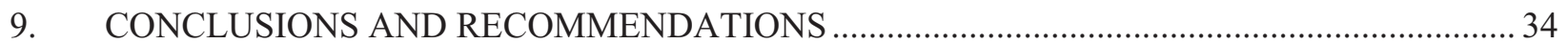




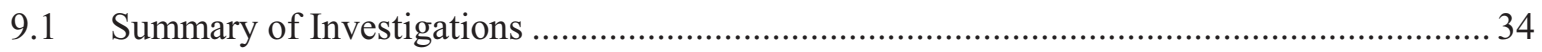

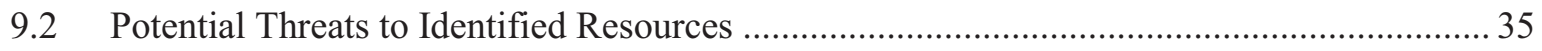

9.3 Relationship of Identified Resources to Project Impacts ................................................... 35

9.4 Recommendations for Additional Investigations or Protective Measures ............................. 38

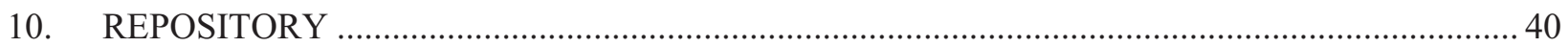

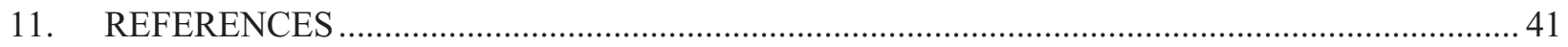

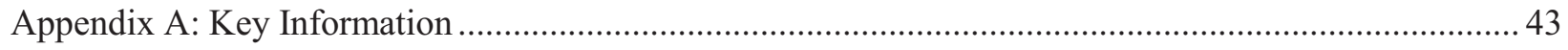

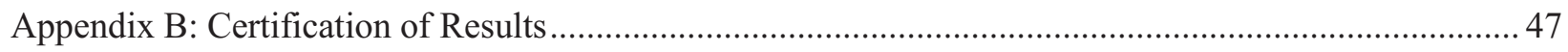

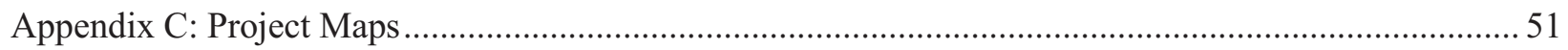

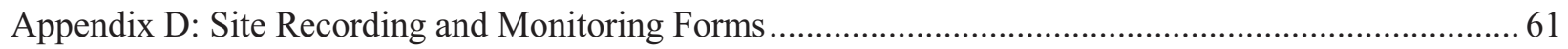

\section{FIGURES}

Figure 1. General location of the Idaho National Laboratory.............................................................. 1

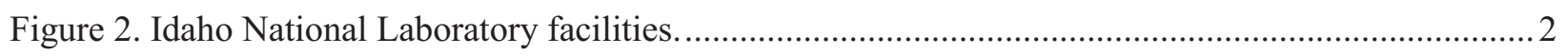

Figure 3. Proposed alternatives for the new haul road.................................................................... 3

Figure 4. Proposed road center line and new archaeological survey coverage for the western end of the preferred alternative for haul road construction south of the power line and T-25...........5

Figure 5. Proposed road center line and new archaeological survey coverage for the central portion of the preferred alternative for haul road construction south of the power line and $\mathrm{T}-25 . . . . . . .$.

Figure 6. Proposed road center line and new archaeological survey coverage for the eastern end of the preferred alternative for haul road construction south of the power line and T-25.......... 7

Figure 7. Proposed road center line and previous archaeological survey coverage for the western end of the T-24 alternative for haul road construction. ..........................................................

Figure 8. Proposed road center line and previous archaeological survey coverage for the middle portion of the T-24 alternative for haul road construction....................................................

Figure 9. Proposed road center line and previous archaeological survey coverage for the eastern end of the T-24 alternative for haul road construction. ............................................................. 10

Figure 10. Facing west, general area of site 10-BT-1059, unaffected by range fire............................... 17

Figure 11. Facing southwest, general area of site 10-BM-112, burned between 1985 and 2005............. 18

Figure 12. Facing east, general area of site 10-BT-1049, after 2008 fire and subsequent new soil deposition.

Figure 13. Typical isolated artifacts discovered in the preferred alternative for haul road construction south of the T-25 power line road (BEA-2010-11-10).

Figure 14. Archaeological sites BEA-2010-11-07 (foreground) and 10-BT-1049 (distant background) are located in an area where wind erosion has exposed many artifacts................ 31

Figure 15. Newly discovered large side-notched point fragment from 10-BT-1049 ............................. 32 


\section{TABLES}

Table 1. Project and survey acreage

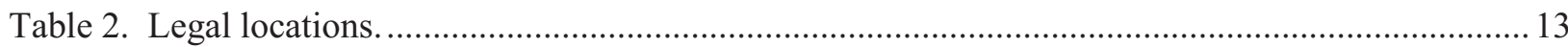

Table 3. Previously recorded archaeological resources in the preferred alternative for haul road construction south of the T-25 power line road.

Table 4. Previously recorded archaeological resources in the alternative for haul road

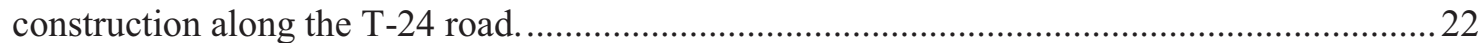

Table 5. General themes and time periods anticipated in the project area.............................................23

Table 6. INL-specific contexts anticipated in the project area.............................................................23

Table 7. Archaeological resources recorded in the preferred alternative for haul road construction south of the T-25 power line road.

Table 8. Relationship of identified resources in the preferred alternative for haul road construction south of the power line and T-25 to anticipated project impacts and recommended protection measures 


\section{ACRONYMS}

\begin{tabular}{|c|c|}
\hline AIP & Agreement in Principle \\
\hline ATR & Advanced Test Reactor \\
\hline BEA & Battelle Energy Alliance \\
\hline BM & Bingham (county) \\
\hline BT & Butte (county) \\
\hline BP & before present (years) \\
\hline CERCLA & Comprehensive Environmental Response, Compensation, and Liability Act \\
\hline CFA & Central Facilities Area \\
\hline CITRC & Critical Infrastructure Test Range Complex \\
\hline $\mathrm{cm}$ & centimeters \\
\hline CRM & cultural resource management \\
\hline CWI & CH2M-WG Idaho, LLC \\
\hline DOE-ID & Department of Energy-Idaho Operations Office \\
\hline $\mathrm{ft}$ & feet \\
\hline GIS & geographical information systems \\
\hline GPS & global positioning system \\
\hline INL & Idaho National Laboratory \\
\hline INTEC & Idaho Nuclear Technology and Engineering Center \\
\hline MFC & Materials and Fuels Complex \\
\hline $\mathrm{m}$ & meters \\
\hline NRF & Naval Reactors Facility \\
\hline NRHP & National Register of Historic Places \\
\hline SHPO & State Historic Preservation Office \\
\hline U.S. & United States \\
\hline
\end{tabular}




\section{Cultural Resource Investigations for a Multipurpose Haul Road at the Idaho National Laboratory \\ 1. INTRODUCTION}

The Idaho National Laboratory (INL) is an 890 square mile federal reserve covering portions of five counties on the northeastern edge of the Snake River Plain in southeastern Idaho (Figure 1). INL lands and facilities are under the jurisdiction of the U.S. Department of Energy, Idaho Operations Office (DOEID) and have been set aside since the 1940s to support science and engineering in nuclear energy and other disciplines (Stacy 2000). The Laboratory has also been designated a National Environmental Research Park, dedicated to the study of the environmental impacts of energy research (Irving 1993), and a portion of the land has been set aside as a Sagebrush Steppe Ecosystem Reserve. Cultural resources including historic and prehistoric archaeological sites, historic architectural properties, and areas of importance to the Shoshone-Bannock Tribes and others are numerous across the Laboratory and are managed in accordance with the DOE-ID's Cultural Resource Management (CRM) Plan (DOE-ID 2009).

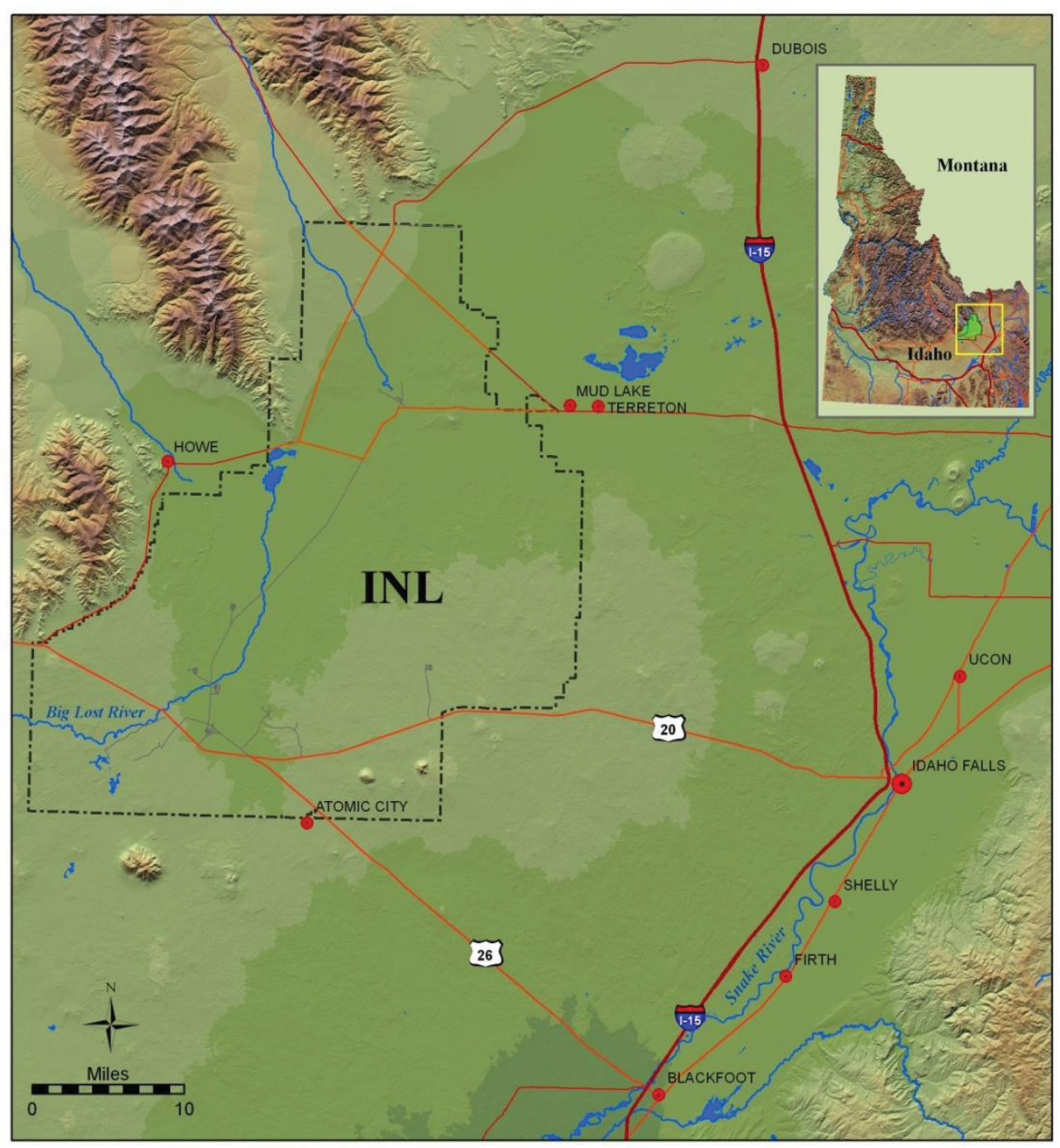

Figure 1. General location of the Idaho National Laboratory. 
Since its establishment in 1949 as the National Reactor Testing Station, the INL has made significant scientific contributions to the development of nuclear power across the Nation. This trend continues today as INL is designated as the lead national laboratory for development of new nuclear reactor technology. Various support systems are necessary to continue this important work. Among them is a capability to safely transport materials and equipment between major INL facilities (Figure 2). Currently, all transportation between the Materials and Fuels Complex (MFC) near the eastern boundary of the Laboratory and other interior INL Site facilities is via U.S. Highway 20 or along unimproved two-track trails. In order to reduce shipment costs, improve operational efficiency, improve highway safety, and reduce impacts to the public by minimizing public road closures, the DOE-ID proposes to provide an alternative route to support transportation needs over the next decade or more (DOE-ID 2010).

This report documents archival research and field investigations to identify cultural resources located in the two preferred alternative routes for construction of this new road. Recommendations for future strategies to avoid any adverse impacts to identified cultural resources are also included. The document is presented in a specific format preferred by the Idaho State Historic Preservation Office (Idaho SHPO 1995) and required by the INL CRM Plan (DOE-ID 2009).

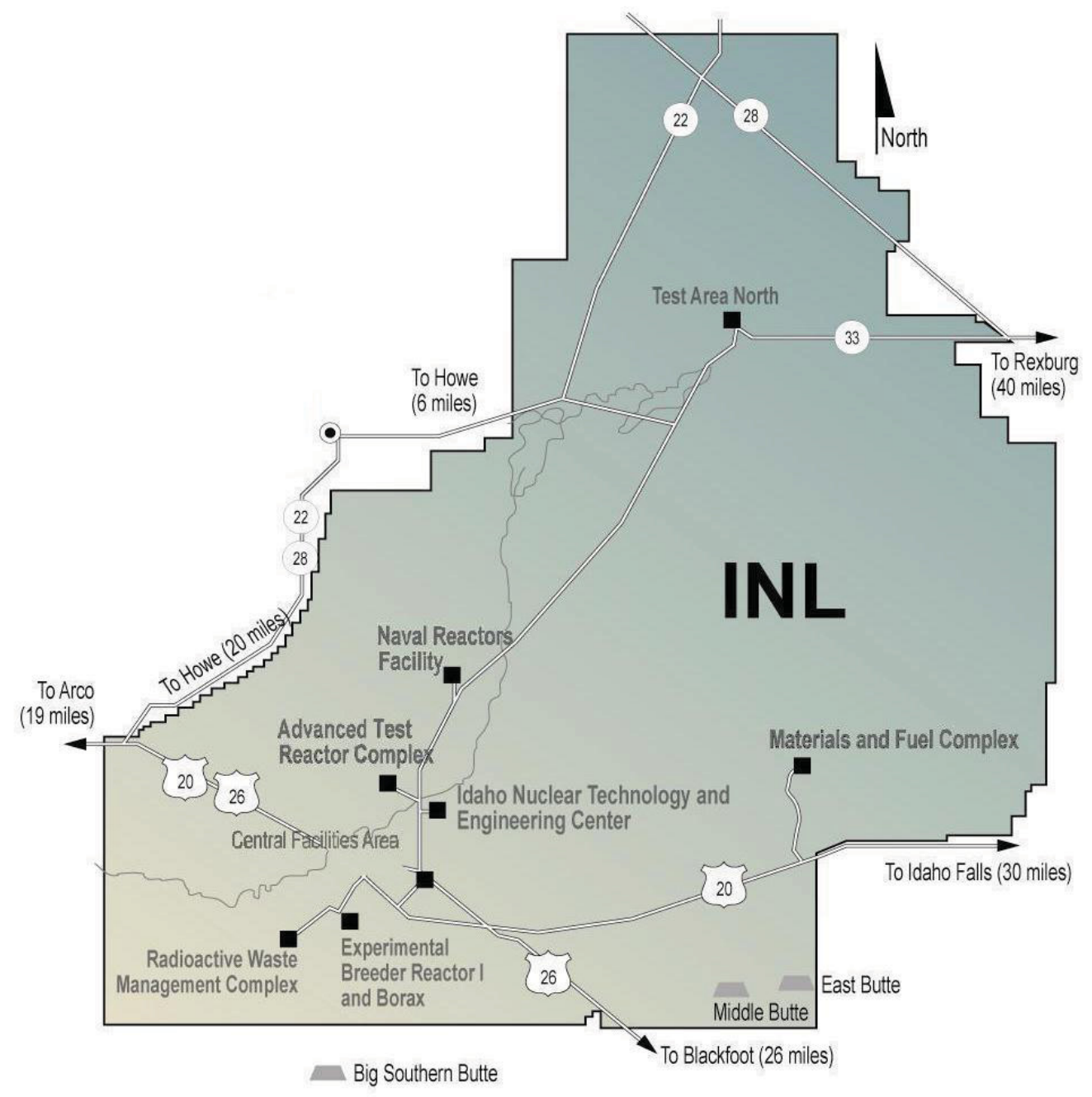

Figure 2. Idaho National Laboratory facilities. 


\section{PROJECT DESCRIPTION}

To meet INL's need for efficient, cost-effective, flexible transport of materials, a nonpublic road between MFC and other INL facilities and existing paved road infrastrucutre is proposed (DOE-ID 2010) (Figure 1). Currently, shipments are via public U.S. Highway 20, which requires periodic closures of U.S. Highway 20. An internal road would allow shipments between facilities without impacting public access. Overall highway safety would also be improved with the proposed road and the cost and time required for routine shipments would be reduced through improved operational efficiency. Two primary alternatives are under consideration for the construction; the preferred route travels south of a power line maintenance road known as T-25 and a second route follows an existing two-track trail known as T-24.

The new multipurpose haul road will be designed for a 100,000-lb gross vehicle weight, double-drop, three-axle trailer with 6-inch ground clearance. Design would be for maximum speed of 35 miles per hour with the ability for oncoming trucks to pass, accommodated either by road width or turnouts at appropriate intervals. Either alternative would require clearing and grading a base, installing necessary culverts and drainage, and placing and compacting gravel for the road surface. The finished road is likely to be at least $25 \mathrm{ft}$ wide with $10 \mathrm{ft}$ shoulders on either side. When the road is completed, access would be controlled for maintenance and official shipments only.

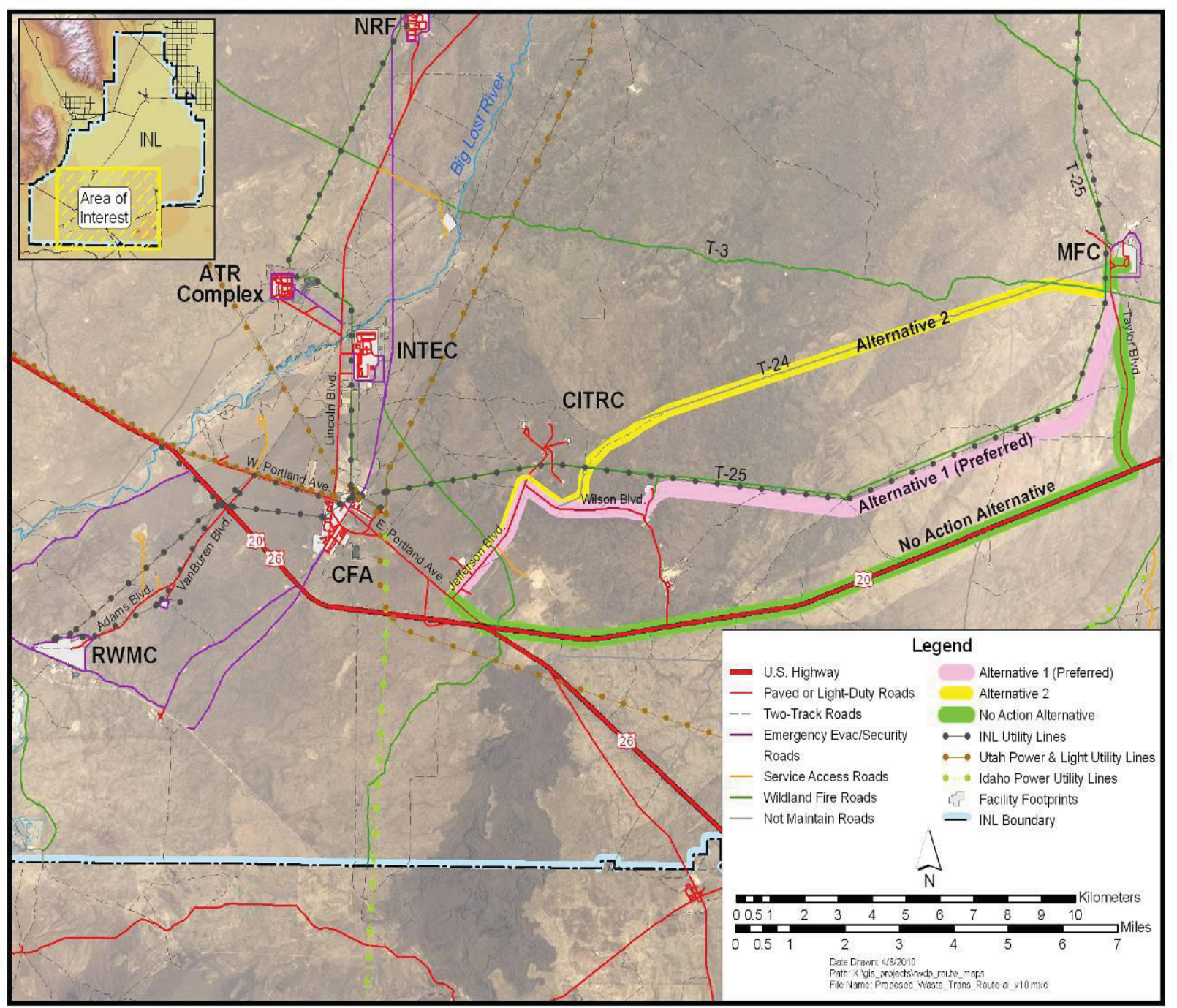

Figure 3. Proposed alternatives for the new haul road. 


\subsection{Areas of Potential Effect}

There are two areas of potential effect for the proposed multipurpose haul road. The center line of the preferred alternative is situated approximately $100 \mathrm{ft}$ south of the power lines and associated maintenance road T-25. This route extends approximately 10 miles west from MFC, then $1 / 4$ mile south along a gravel road cutoff that leads to rough pavement on Filmore Blvd (Figures 4, 5, and 6). The second alternative is centered on a 10 mile long stretch of road T-24 from MFC west, then south along another rough two-track trail that follows the fenced perimeter of the Critical Infrastructure Test Range Complex (CITRC) for just over a mile, ending at pavement on Wilson Blvd (Figures 7, 8, and 9). Along both routes, a direct impact construction zone of approximately $30 \mathrm{ft}$ width is assumed at this time, although this may change based on specific field conditions and design requirements (i.e. steep grades may require wider shoulders, culverts may impact a wider area, etc.).

Extensive changes will be necessary to utilize either route for waste transportation, including grading, leveling, graveling, and compaction. In some rocky areas blasting may be necessary to remove basalt bedrock. Low areas and steeper hills may require extensive fill to create grades that are suitable and safe for the anticipated shipments. Drainage channels and culverts may be necessary in some places. The width of the new road is expected to be approximately $25 \mathrm{ft}$, wide enough to allow passage of two vehicles, with shoulders of varying widths, depending on final design and grade. Due to security requirements, access to the new road will be restricted to official INL business and it is likely that gates will be installed at either end of the route with padlocks and warning signs to prevent unauthorized access.

Any archaeological resources and/or natural resources of importance to the Shoshone-Bannock Tribes located on the proposed centerline of the new road or within approximately $10-20 \mathrm{ft}$ of it, depending on final design, could be subject to direct impact during construction. Impacts will primarily result from heavy equipment operations and possible blasting. Once construction is completed and the new multipurpose haul road is in operation, new direct impacts are unlikely. However, indirect impacts to cultural resources may result from an increase in overall activity in a previously undeveloped portion of the INL. Archaeological sites, wildlife, and plants may be impacted by increased traffic, introduction and spread of invasive/noxious weeds, casual visitation, or unauthorized artifact collection.

\subsection{Project Acreage}

The preferred alternative route south of the power line and T-25 at $120 \mathrm{ft}$ in width encompasses approximately 151 acres. The T-24 alternative at the same $120 \mathrm{ft}$ width encompasses approximately 164 acres. These figures are summarized in Table 1. Intensive cultural resource surveys have exceeded these project acreages along both roads, ensuring complete coverage of both areas of potential effect.

Table 1. Project and survey acreage.

\begin{tabular}{|c|c|c|}
\hline ALTERNATIVE & AREA OF POTENTIAL EFFECT & $\begin{array}{l}\text { ARCHAEOLOGICAL } \\
\text { SURVEY COVERAGE }\end{array}$ \\
\hline $\begin{array}{l}\text { Preferred Alternative } \\
\text { (south of T-25) }\end{array}$ & $\begin{array}{l}\text { Corridor south of power line and T-25: } 36.36 \\
\text { acres ( } \sim 10 \text { miles long, } 30 \mathrm{ft} \text { wide) } \\
\text { Cutoff to Filmore Blvd.: } 1.45 \text { acres }(\sim 0.4 \\
\text { mile long, } 30 \mathrm{ft} \text { wide) }\end{array}$ & $\begin{array}{l}\text { New intensive survey of } \\
\quad 341 \text { acres } \\
\text { (10.4 miles long, } 262 \mathrm{ft}[80 \mathrm{~m}] \\
\text { wide plus additional acreage at } \\
\text { corners) }\end{array}$ \\
\hline $\mathrm{T}-24$ & $\begin{array}{l}\text { Existing two-track trail: } 36.65 \text { acres }(10 \text { miles } \\
\text { long, } 30 \mathrm{ft} \text { wide) } \\
\text { Cutoff along CITRC fence: } 4.25 \text { acres }(\sim 1.17 \\
\text { miles long, } 30 \mathrm{ft} \text { wide) }\end{array}$ & $\begin{array}{l}\text { Previous intensive survey of } \\
523 \text { acres } \\
\text { (11.25 mile long, } 328 \mathrm{ft}[100 \\
\text { m] wide })\end{array}$ \\
\hline
\end{tabular}




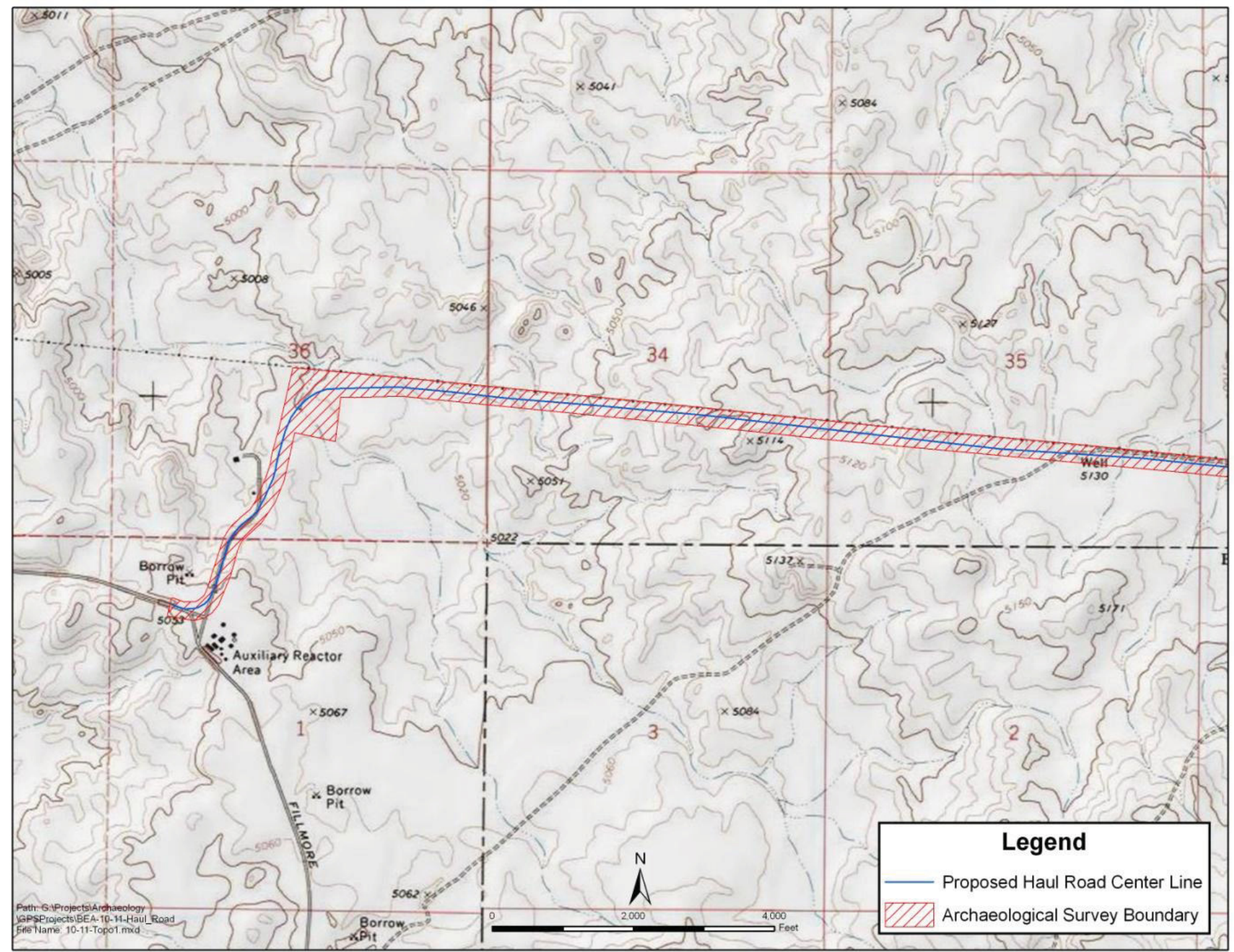

Figure 4. Proposed road center line and new archaeological survey coverage for the western end of the preferred alternative for haul road construction south of the power line and T-25. 


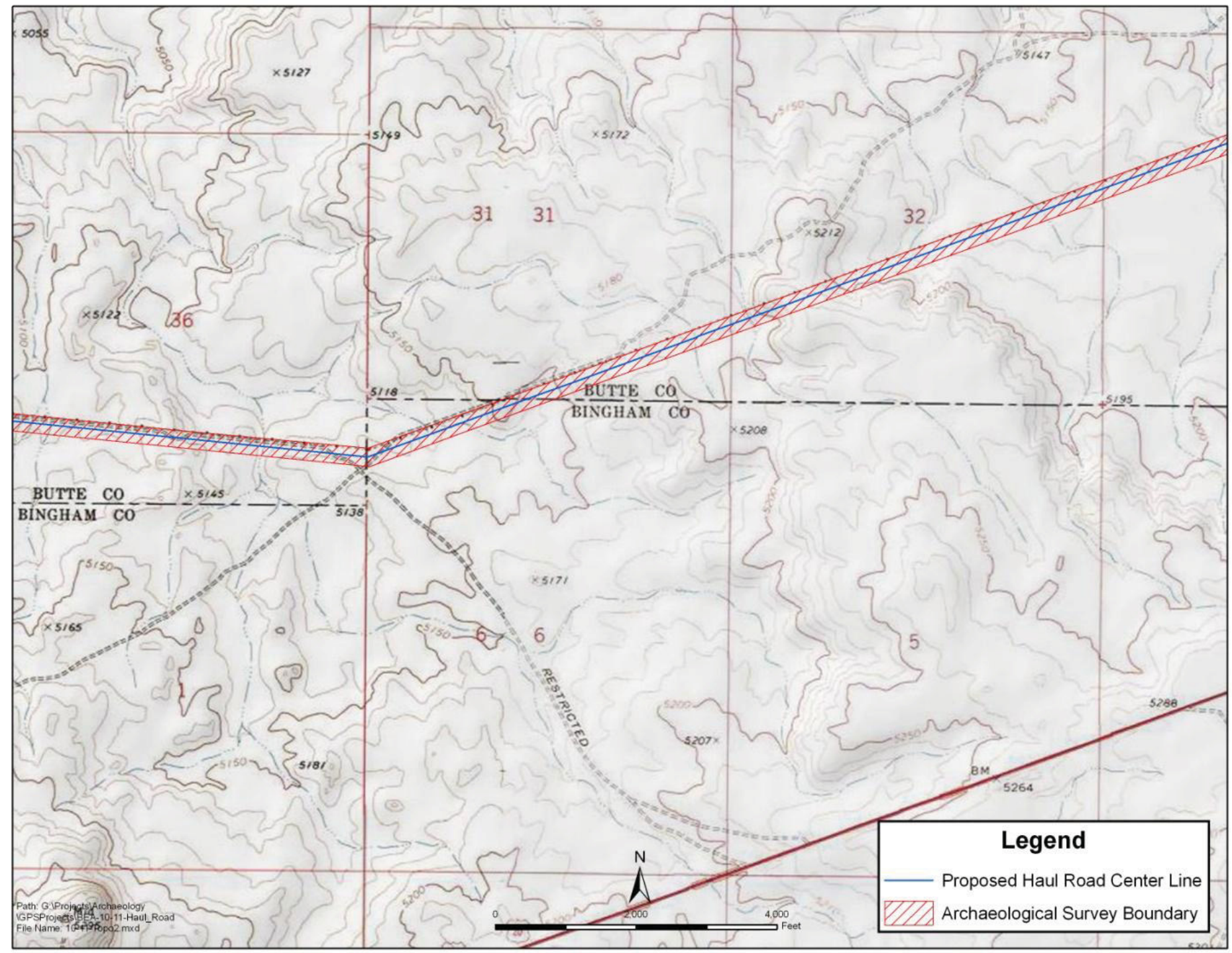

Figure 5. Proposed road center line and new archaeological survey coverage for the central portion of the preferred alternative for haul road construction south of the power line and T-25. 


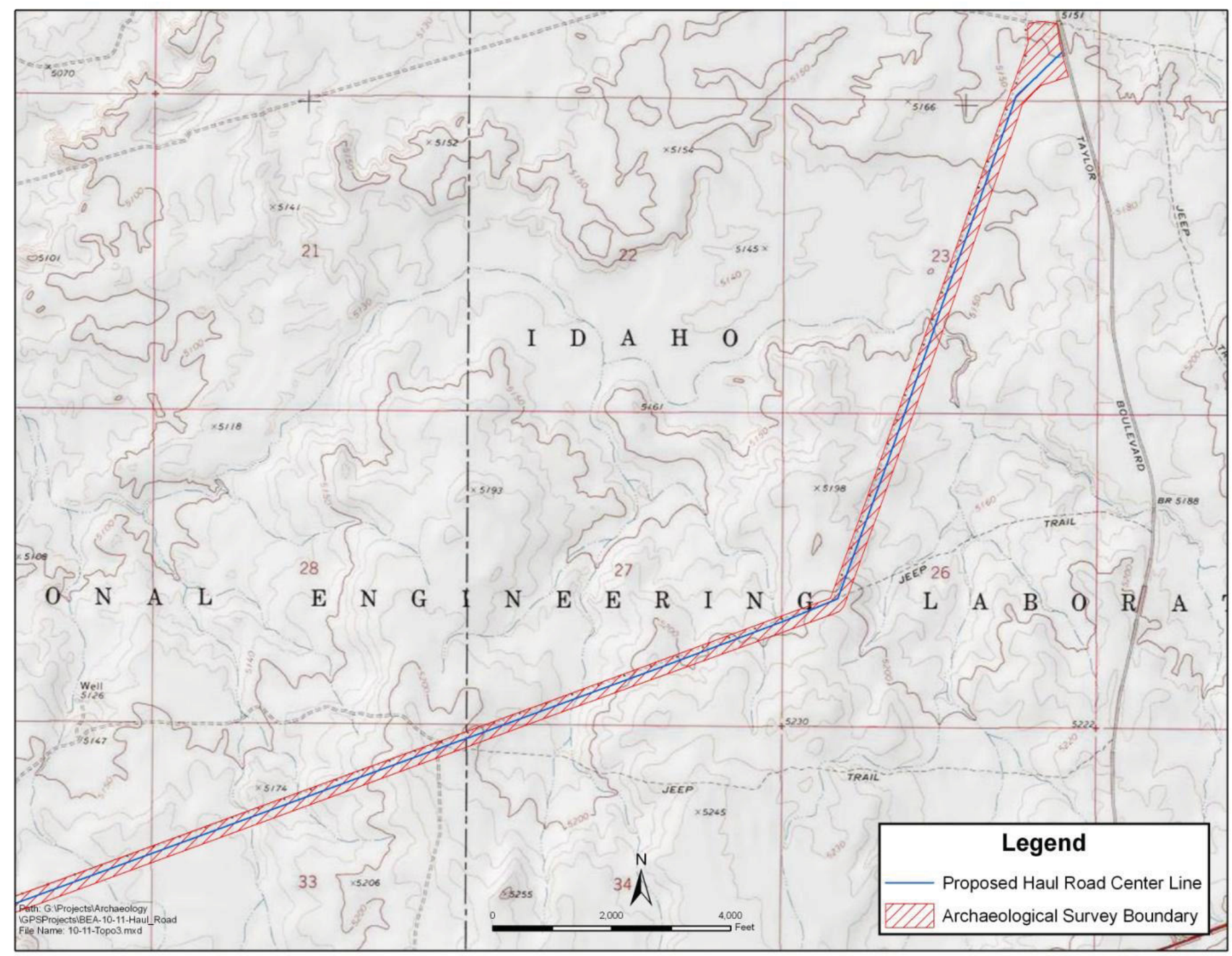

Figure 6. Proposed road center line and new archaeological survey coverage for the eastern end of the preferred alternative for haul road construction south of the power line and T-25. 


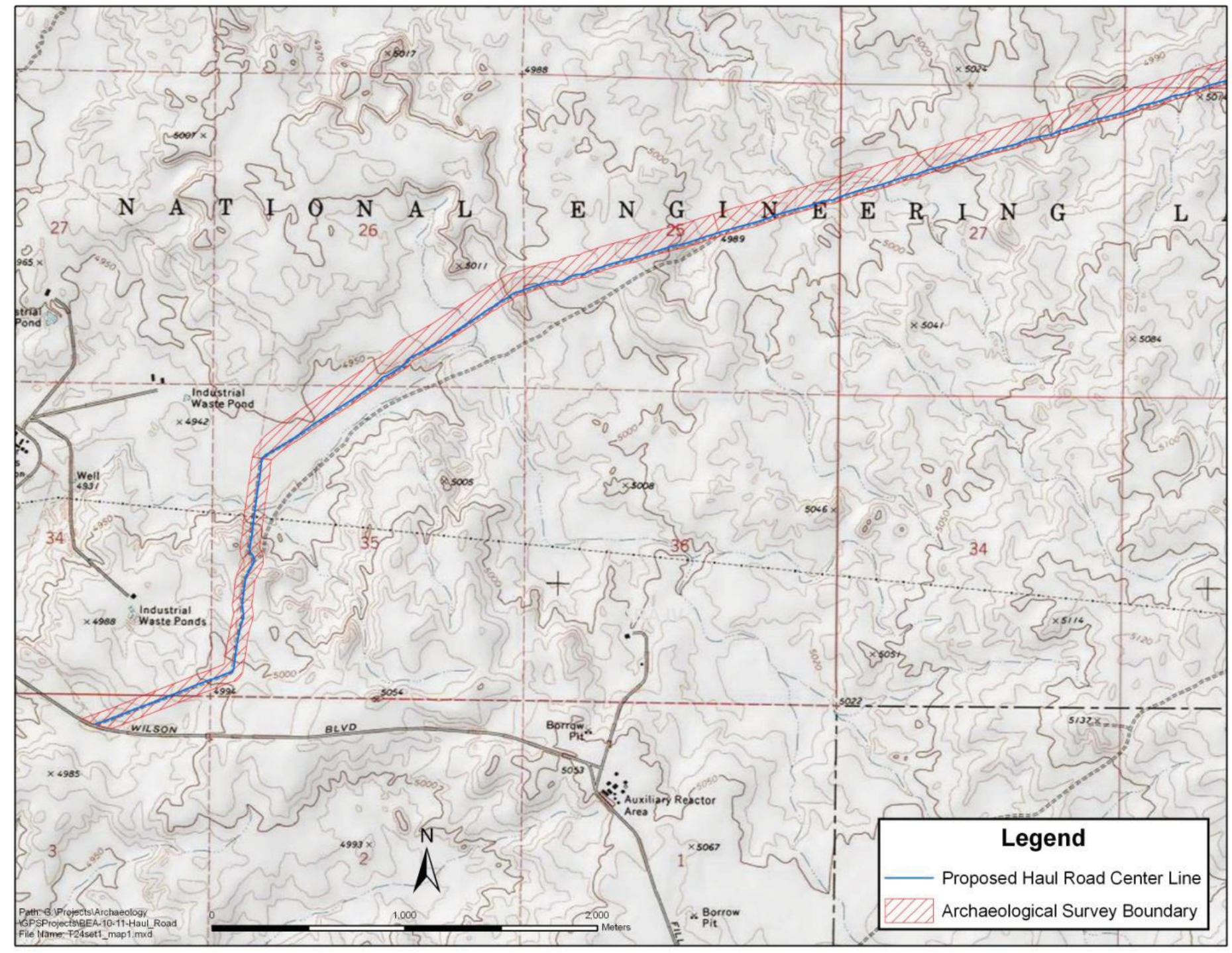

Figure 7. Proposed road center line and previous archaeological survey coverage for the western end of the T-24 alternative for haul road construction. 


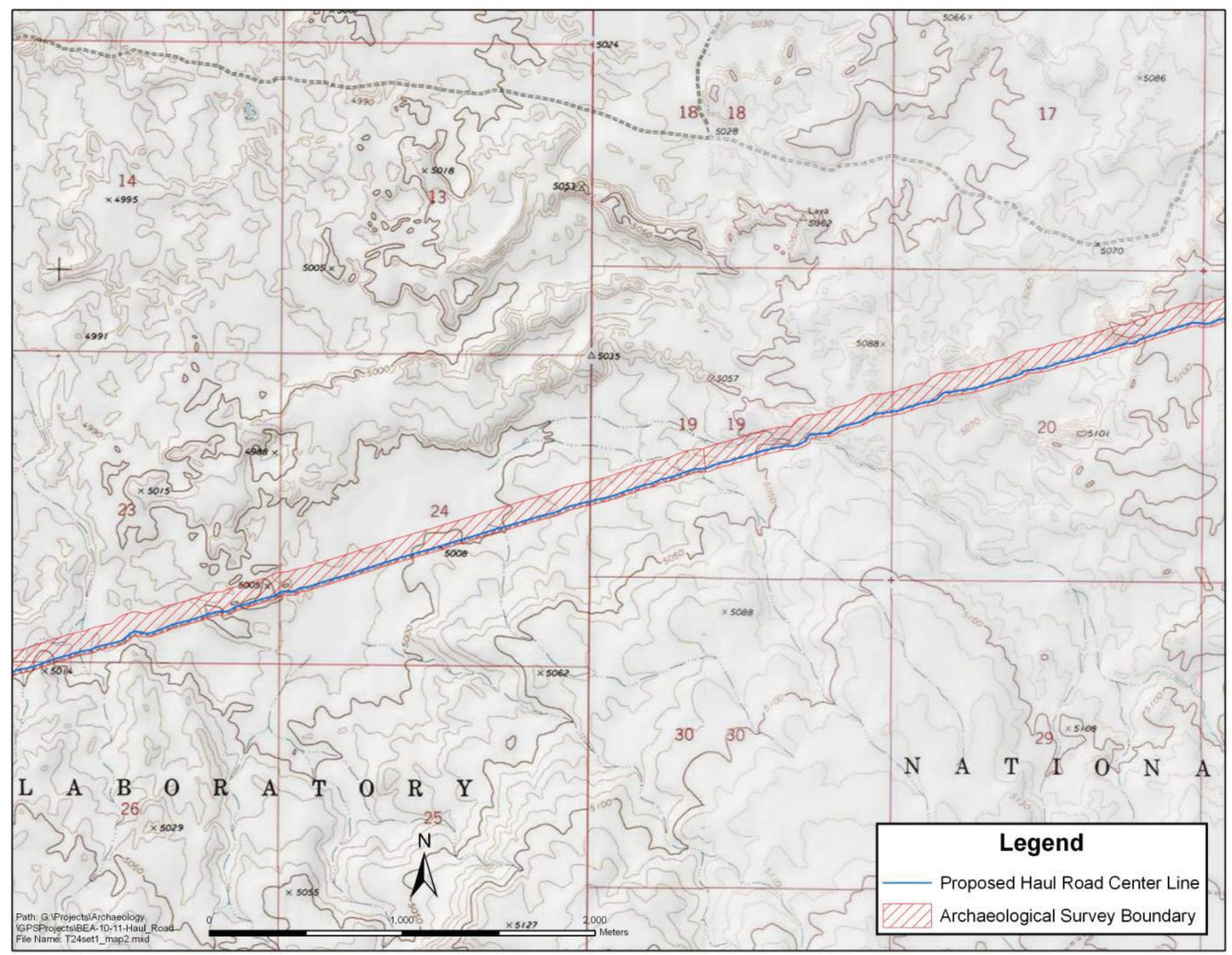

Figure 8. Proposed road center line and previous archaeological survey coverage for the middle portion of the T-24 alternative for haul road construction. 


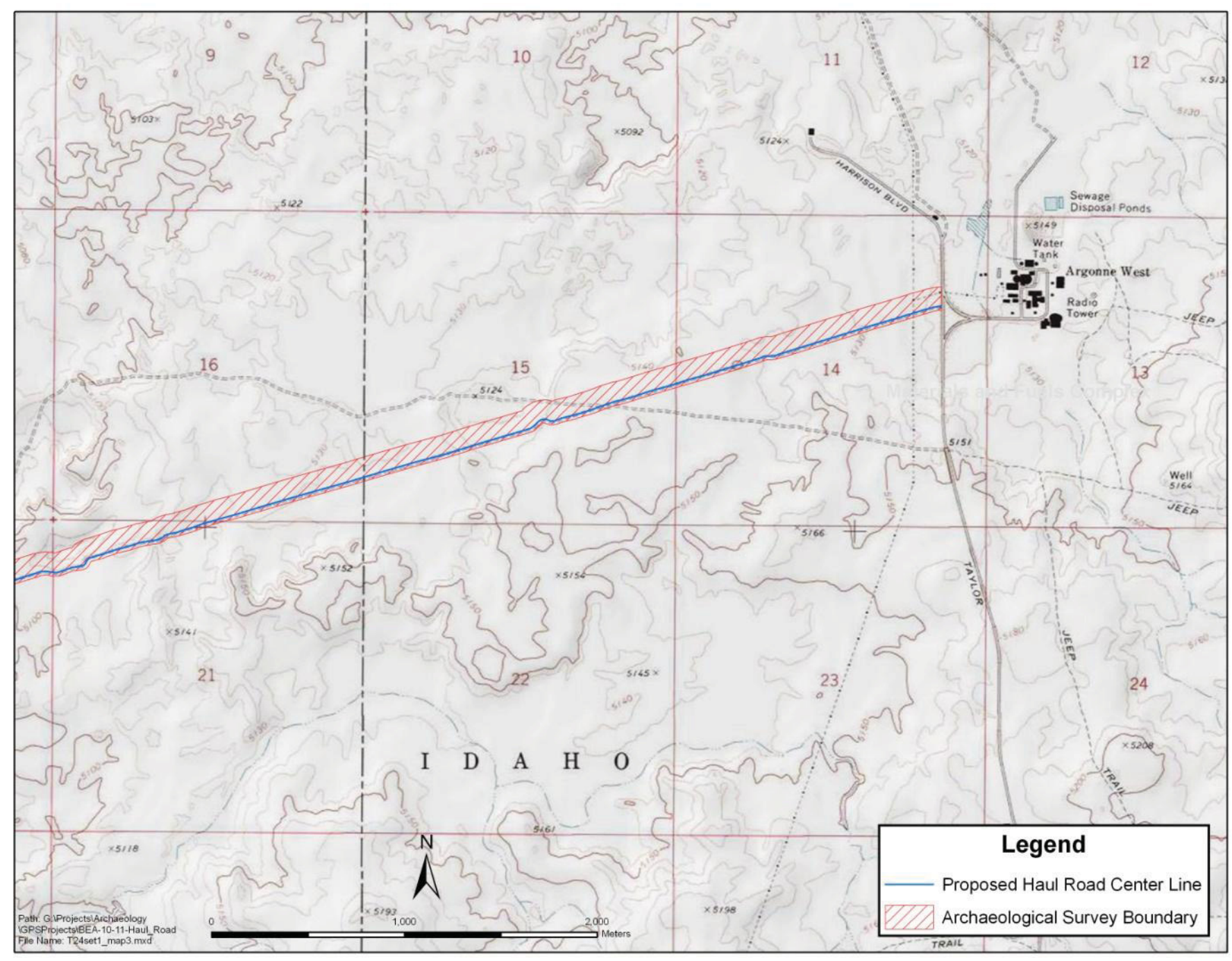

Figure 9. Proposed road center line and previous archaeological survey coverage for the eastern end of the T-24 alternative for haul road construction. 


\subsection{Landowner}

Lands within the boundaries of the INL Site are under the jurisdiction of the U.S. Department of Energy, Idaho Operations Office with the assistance of DOE-ID's prime operations contractor, Battelle Energy Alliance (BEA) and the Idaho Cleanup Project contractor, CH2M-WG Idaho, LLC (CWI). Lands within the Naval Reactors Facility are not administered by DOE-ID. Within INL grazing areas, administration is also shared with the Bureau of Land Management, Upper Snake River District, which issues and administers permits for these activities. Both of the alternative routes for construction of the multipurpose haul road are located on lands under the sole jurisdiction of DOE-ID. 


\section{STATEMENT OF OBJECTIVES FOR INVESTIGATIONs}

The cultural resource investigations reported herein were conducted to satisfy three basic and interrelated goals:

- Identify cultural resources within the two alternative routes for construction of the multipurpose haul road

- Conduct a preliminary assessment of the potential effects of construction activities on any identified cultural resources, particularly those listed on or eligible for listing on the National Register of Historic Places

- Develop recommendations for strategies to help ensure that effects to identified cultural resources are not adverse when construction plans are finalized

\subsection{Description of Area Investigated}

The two roads under consideration for construction pass through 10-12 miles of largely undisturbed lands in the south-central portion of INL north of U.S. Highway 20. A number of cultural resource investigations have been conducted along the roads over the past two decades. A summary is provided in Section 5.0.

To supplement earlier investigations, in 2010 intensive archaeological surveys were completed along the preferred alternative route south of the power line and T-25. In this area a $262 \mathrm{ft}(80 \mathrm{~m})$ wide corridor was intensively surveyed and several wider areas were examined where sharp corners may require smoothing. Only limited field reconnaissance at resources known to extend into the road was conducted along the previously surveyed area of potential effects along the T-24 alternative. Tribal feedback was also sought in 2010 on the cultural resources of each road. Results of these discussions are incorporated into Section 8.0 along with descriptions of resources revisited or newly recorded during the survey of the preferred alternative south of the power line and T-25. The report concludes with recommendations for future work to protect identified resources (Section 9.0).

\subsection{Amount and Types of Information Collected}

All cultural resources investigations completed at INL must meet the Secretary of the Interior's standards under 36 CFR Part 800, as well as the tailored requirements outlined in the INL CRM Plan (DOE-ID 2009). In general, ground disturbing projects at INL are preceded by several types of data collection including: cultural resource archive searches, archaeological reconnaissance surveys in previously examined areas, and/or intensive archaeological surveys in areas that have never been systematically inventoried for cultural resources. Representatives from the Shoshone-Bannock Tribes are involved in INL field surveys and are invited to assist in the identification and protection of resources of traditional cultural or religious importance. All of these activities are designed to identify cultural resources in the areas of potential effect for proposed activities.

Investigations conducted to support the multipurpose haul road project were designed to ensure that all archaeological resources with visible surface remains were identified within the areas of potential effect for construction along the two alternative routes. Representatives from the Shoshone-Bannock Tribe's Heritage Tribal Office were also escorted to view the alternative routes to identify Native American cultural resources. Once plans for the actual road construction are finalized, additional cultural resource coordination will be necessary to ensure that resources with potential for nomination to the National Register of Historic Places are not adversely impacted by construction. Section 9.0 provides recommendations for the archaeological investigations, construction monitoring, and coordination that will accomplish this protection. 


\section{LOCATION AND GENERAL ENVIRONMENTAL SETTING}

The proposed alternatives for a new multipurpose haul road connecting MFC to other internal INL site facilities and paved roads are positioned in the south-central portion of the Laboratory approximately two to four miles north of U.S. Hwy 20. Figures 4 through 9 illustrate the locations. A companion set of maps included in Appendix $\mathrm{C}$ depict archaeological resources identified within the alternative routes.

\subsection{Legal Locations}

Specifically, the alternative routes pass through the townships, ranges, and sections in Butte and Bingham Counties listed in Table 2.

Table 2. Legal locations.

\begin{tabular}{|c|l|}
\hline $\begin{array}{c}\text { AREA OF POTENTIAL } \\
\text { EFFECTS }\end{array}$ & \multicolumn{1}{c|}{ LEGAL LOCATION } \\
\hline $\begin{array}{c}\text { Preferred Alternative } \\
\text { (south of T-25) }\end{array}$ & $\begin{array}{l}\text { Sections 14, 23, 26, 27, 34, T3N, R32E, Bingham County } \\
\text { Sections 31, 32, 33, 34, 35, 36, T3N, R31E, Butte County } \\
\text { Section 6, T2N, R31E, Butte County } \\
\text { Section 36, T3N, R30E, Butte County }\end{array}$ \\
\hline T-24 & Sections 14, 15, T3N, R32E, Bingham County \\
& Sections 16, 19, 20, 21, 23, 24, 26, 27, T3N, R31E, Butte County \\
& Sections 25, 26, 34, 35, T3N, R30E, Butte County \\
& Section 3, T2N, R30E, Butte County \\
\hline
\end{tabular}

\subsection{Setting}

The INL is located in the high cool desert environment of the northeastern Snake River Plain. Aeolian, alluvial, and lacustrine sediments of varying thicknesses overlie basaltic lava flows within the 890 square mile Laboratory complex. The Big Lost River flows in a northeasterly direction from the southwestern corner of the Laboratory to eventually terminate in a series of natural sinks near the foothills of the Lemhi Mountains. An extensive floodplain follows the course of the River and in the vicinity of the sinks, a myriad of channels is cut into the now-dry bed of Pleistocene Lake Terreton.

Vegetation is generally sparse and dominated by a community of low shrubs like sage and rabbitbrush, a wide variety of grasses and forbs, and occasional juniper trees. Many animals make their homes in this sagebrush grassland including pronghorn, deer, elk, coyotes, badgers, rabbits, many birds including raptors, game birds, and waterfowl, a wide variety of small rodents, and several types of small reptile.

Additional details on INL human history are provided in INL's Cultural Resource Management Plan (DOE-ID 2009). In general, the entire region has long been attractive to human populations. For Native American hunter-gatherers who probably utilized the area on a seasonal basis over at least 12,000 years, game animals and useful plants were found in abundance and nearby Big Southern Butte was attractive for the obsidian toolstone that outcrops near its crest.

Within the last 150 years, emigrants began to pass through the area along a northern spur of the Oregon Trail (Goodale's Cutoff). Soon thereafter, early homesteaders sought to harness the waters of the Big Lost River and transform sagebrush flats into green pastures. Hundreds of settlers were encouraged 
by various federal laws like the Desert Land Act of 1877 and Carey Land Act of 1894 to file claims for INL lands at this time (ca. 1878 - 1930) and a massive system of canals and ditches was constructed to irrigate the newly created fields.

Few of these early settlers were able to "prove-up" on their claims and by 1930 most of the homesteads were abandoned. By the early 1940s, the remote and largely uninhabited lands that remained became attractive to the U.S. government for establishment of a Naval Proving Ground to test fire large battleship guns and conduct other ordnance-related research in support of U.S. military applications during World War II. After this initial period of military use, the U.S. Atomic Energy Commission designated the land as the National Reactor Testing Station and it became the Nation's primary testing ground for an emerging nuclear research program after 1949. The Laboratory has filled a similar role for more than 50 years, ultimately influencing nearly every power reactor in the world particularly in regard to design and safety (Stacey 2000).

Both routes extending west from MFC pass through similar topographic situations. Primary landforms are volcanic in origin and consist of low-relief basaltic pressure ridges and closed basins that add variation to the generally flat terrain. Exposures of basalt bedrock are common along ridge tops and aeolian sands have accumulated in some areas, creating dune pockets. Elevations along both routes average 5,150 ft and range between 4,950 and 5,200 ft. Plant life is typical of INL as a whole, dominated by low shrubs (sagebrush, rabbitbrush), various grasses, and forbs. In the sandier areas, tall sage and prickly pear are notable. Thicker accumulations of sediment are evident in the basins and grasses dominate the vegetation community. Intermittent drainages cut through the lava plains, providing seasonal moisture via local runoff to support the grassy vegetation during periods of increased moisture. Along T-24, where the terrain is more rugged, ridges are higher and basins are deeper, with drops in elevation reaching up to $60 \mathrm{ft}$ in some areas and average drops around $20-30 \mathrm{ft}$. A long linear feature that cuts across T-24 in one topographically diverse area is probably a collapsed lava tube. Several sections of the preferred alternative south of T-25 have burned in recent range fires and winds have redeposited significant amounts of sand and fine ashy silt in portions of this area. 


\section{PRE-FIELD RESEARCH}

The INL CRM Office maintains an active archive of cultural resource investigations conducted at INL. This includes a wide variety of supporting documentation as well as the following specific records:

- Reports of reconnaissance-level archaeological surveys completed before 1984

- Reports of intensive archaeological surveys completed after 1984, including site forms

- Reports of archaeological test excavations conducted on INL lands, including field notes

- Archaeological sensitivity maps with predicted resource densities (Ringe 1995, Holmer et al. 2002)

- Maps and survey notes from government-sponsored land surveys of INL lands, ca 1884-1949

- Historic aerial photos of INL lands taken in 1949

- Reports of architectural surveys of all DOE-ID owned INL buildings (Arrowrock 1997)

- Historic and current plot plans of INL buildings and facility areas

- Microsoft Access and geographical information systems (GIS) maps and databases with information specific to the archaeological sites and historic architectural properties identified at INL.

All archaeological investigations completed at INL are preceded by checks of these archival materials to determine the nature and extent of previous research in a given area.

\subsection{Sources of Information Checked}

Several sources of information were consulted prior to 2010 field work for the multipurpose haul road, including the following specific records:

- INL CRM project files

- INL CRM archaeological site databases and GIS maps

- Archaeological survey reports

- Historic aerial photographs of the project area taken in 1949

\subsection{Summary of Previous Investigations}

Archaeological surveys of the T-25 power line road and T-24 began in 1985 when both routes were considered for fiber optic cable installation (Reed et al. 1987). At this time, intensive surveys were conducted within a 100 meter-wide corridor centered on the power line and within a 100 meter-wide corridor north of T-24. A subcontractor from Idaho State University (ISU), the Swanson/Crabtree Anthropological Research Laboratory, completed the work. Several current members of the INL CRM Office were crew leaders and/or crew members on these early projects. Between MFC and the CITRC perimeter, the archaeologists identified 33 resources (15 sites, 18 isolates) along the power line and T-25 and 23 resources (15 sites, 8 isolates) along T-24 between MFC and the CITRC perimeter (Reed et al. 1987). The fiber optic cable was eventually installed north of the T-25 power line road, skirting around the edges of the identified archaeological sites to avoid adverse impacts.

The short stretch of road extending along the CITRC perimeter fence from the end of T-24 to the existing pavement at Wilson Blvd. was also surveyed by ISU archaeologists in 1985 during a site-wide effort to assemble archaeological inventories for all active INL facilities (Reed et al. 1987). At this time, a 100 meter-wide zone surrounding CITRC (then known as the Power Burst Facility) was intensively examined along with more than 1,000 acres inside the fence. As a result of these efforts, 86 sensitive resources have been identified within the fenced perimeter of the facility or immediately adjacent to it. 
Three isolates are located in the stretch of perimeter road and fence line from the end of T-24 to Wilson Blvd.

The lands included in and around CITRC have also proven to be highly sensitive in regard to Native American resources. Human remains have been inadvertently discovered on two occasions. In 1994, remains were discovered in secondary context (Miller 1994) and in 1996 remains were discovered in primary context (Miller 1997). Both of these finds were subject to emergency stabilization and recovery by INL CRM Office archaeologists. Additional finds of this nature may occur in the sandy soils that surround CITRC but no human remains have been discovered at known sites within the areas of potential effect for road construction south of the T-25 power line road or T-24.

In 1988, archaeological test excavations were completed at potentially eligible resources located within the direct impact zone for a major upgrade to the power line (Ringe 1988) to assess the nature and extent of subsurface cultural deposits and make a determination of National Register eligibility. In the ten mile-long stretch south of T-25 considered for new construction today, five archaeological sites were tested (10-BM-112, 10-BM-118, 10-BT-1052, 10-BT-1247, 10-BT-1059). The number of test pits excavated at each site ranged from one to five, depending on the size of the site area contained within 50 $\mathrm{m}$ of the power line. All pits were 1 x $2 \mathrm{~m}$ in size and were taken down in $10 \mathrm{~cm}$ levels measured below ground surface. At one site (10-BM-112), small $30 \times 30 \mathrm{~cm}$ shovel probes were excavated. Excavation in each test pit and shovel probe continued until at least $10 \mathrm{~cm}$ of culturally sterile soil or basalt bedrock was encountered. Soil removed from the test pits was screened through 1/8 inch hardware mesh and all artifacts were collected and curated with accompanying documentation.

Subsurface cultural deposits were confirmed at three sites (10-BT-1052, 10-BT-1247, and 10-BT1059 ) within the preferred alternative for haul road construction south of the power line and T-25 and conversely, two sites (10-BM-112 and 10-BM-118) were determined not to have subsurface materials. As a result of this testing, the two sites that lacked significant subsurface deposits (10-BM-112 and 10BM-118) were evaluated as ineligible for nomination to the National Register of Historic Places and three sites with demonstrated subsurface materials (10-BT-1052, 10-BT-1247, and10-BT-1059) were determined eligible (Ringe 1988). The Idaho SHPO concurred with these evaluations (Green 1989).

In 1997, two archaeological surveys included portions of the ten mile stretch of the T-25 power line road. During one survey for a possible test range to develop materials and equipment for response to natural disasters (INL CRM Archives 1997a), a historic archaeological site was identified south of the power line. Shortly after this survey was completed, this project was cancelled. Later that year, select resources along the power line road were revisited and assessed in advance of the addition of a layer of gravel to portions of the existing roadbed to facilitate power line maintenance and travel from MFC to CITRC and ARA-IV. No new artifacts or features were observed at this time and clearance was recommended for graveling with the stipulation that no gravel be added to any known archaeological site areas, particularly 10-BT-1052, 10-BT-1247, and 10-BT-1059, where sensitive surface and subsurface cultural materials were known to occur (INL CRM Archives 1997b).

In 2005, a five mile-long stretch of the power line road T-25 that had been burned by range fires was re-surveyed and portions of road T-24, including a $20 \mathrm{~m}$ wide zone south of the road, were examined as an initial step in evaluating the potential impact of significant road upgrades (Pace et al. 2005). At this time, the cutoff road to Filmore Blvd, past the ARA-IV facility, to the T-25 power line road was surveyed for the first time. Three new isolate locations, evaluated as ineligible for nomination to the National Register, were identified during this survey project, one along the main T-25 power line road, one along the cutoff leading to Filmore Blvd, and one along T-24. In addition, nine previously recorded sites along T-25 and nine previously recorded sites along T-24 were revisited and determined to be within the areas of potential effect for road upgrades. Finally, a zone of historic sensitivity was also identified north of the $\mathrm{T}-25$ power line road, where early $20^{\text {th }}$ Century agricultural activity appeared to have been concentrated. 
In 2008, INL's National and Homeland Security organization began research activities utilizing the INL power grid, including the power line that runs along the T-25 road. Intensive archaeological surveys were completed for this proposed research in advance of the installation of equipment and structures at two locations to ensure that all sensitive archaeological resources were avoided (INL CRM Archives 2008a). Archaeologists also returned to a portion of the T-25 power line road in July of 2008 while surveying a fire break created during emergency operations associated with a wild land fire. Two previously recorded archaeological sites (10-BT-1053 and 10-BT-1062) along the T-25 power line road were impacted by fire breaks associated with this emergency activity (INL CRM 2008b).

Late in 2008, the INL CRM Office returned to the T-25 power line road to conduct a specific assessment of potential impacts to known archaeological sites during another proposed upgrade to the existing roadway (Pace 2008). New intensive surveys at this time resulted in the documentation of two new isolated artifact locations in the $120 \mathrm{ft}$-wide area of potential effect for proposed road upgrades centered on the existing T-25 road. Fieldwork in 2008 also confirmed the locations of eleven previously recorded prehistoric archaeological sites in the $120 \mathrm{ft}$-wide area of potential effect: 10-BM-109, 10-BM110, 10-BM-112, 10-BM-116, 10-BM-117, 10-BM-118, 10-BT-1049, 10-BT-1052, 10-BT-1053, 10-BT1059, and 10-BT-1062, and three previously recorded prehistoric sites nearby, but just outside of it: 10BM-115, 10-BT-1063, and 10-BT-1247. Artifact assemblages exposed at these sites at this time differed slightly from the original recordings, particularly in areas that had burned. In these places, aeolian sand had accumulated over some site areas, obscuring some artifacts from view, and winds had scoured the surfaces of other areas, exposing additional artifacts. In spite of the changes in artifact visibility, all previously recorded resources remained visible on the landscape and retained the same essential components originally recorded in their assemblages. Figures 10 - 12 illustrate the geomorphic conditions observed in 2008. Similar settings were observed in 2010.

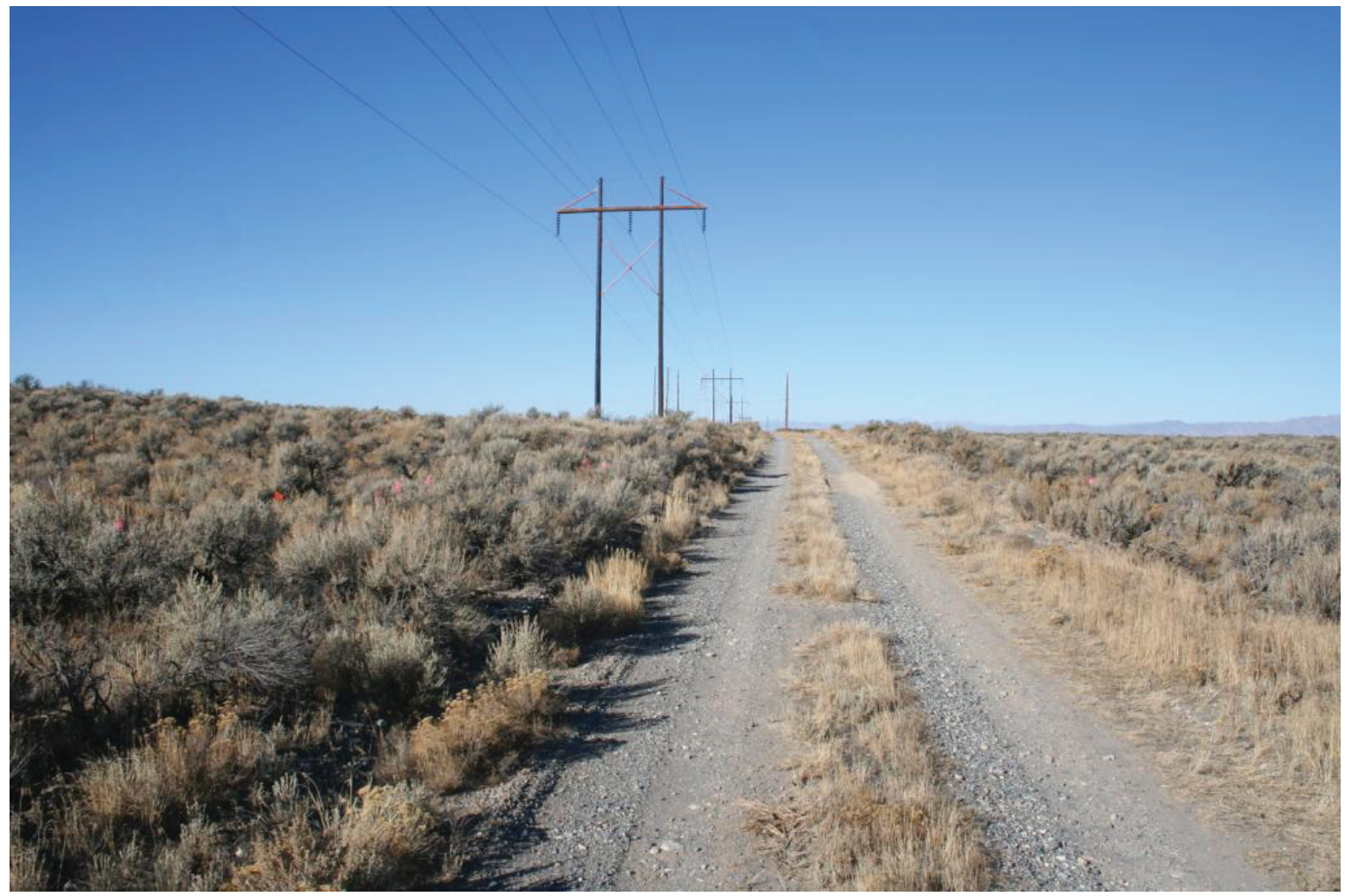

Figure 10. Facing west, general area of site 10-BT-1059, unaffected by range fire. 


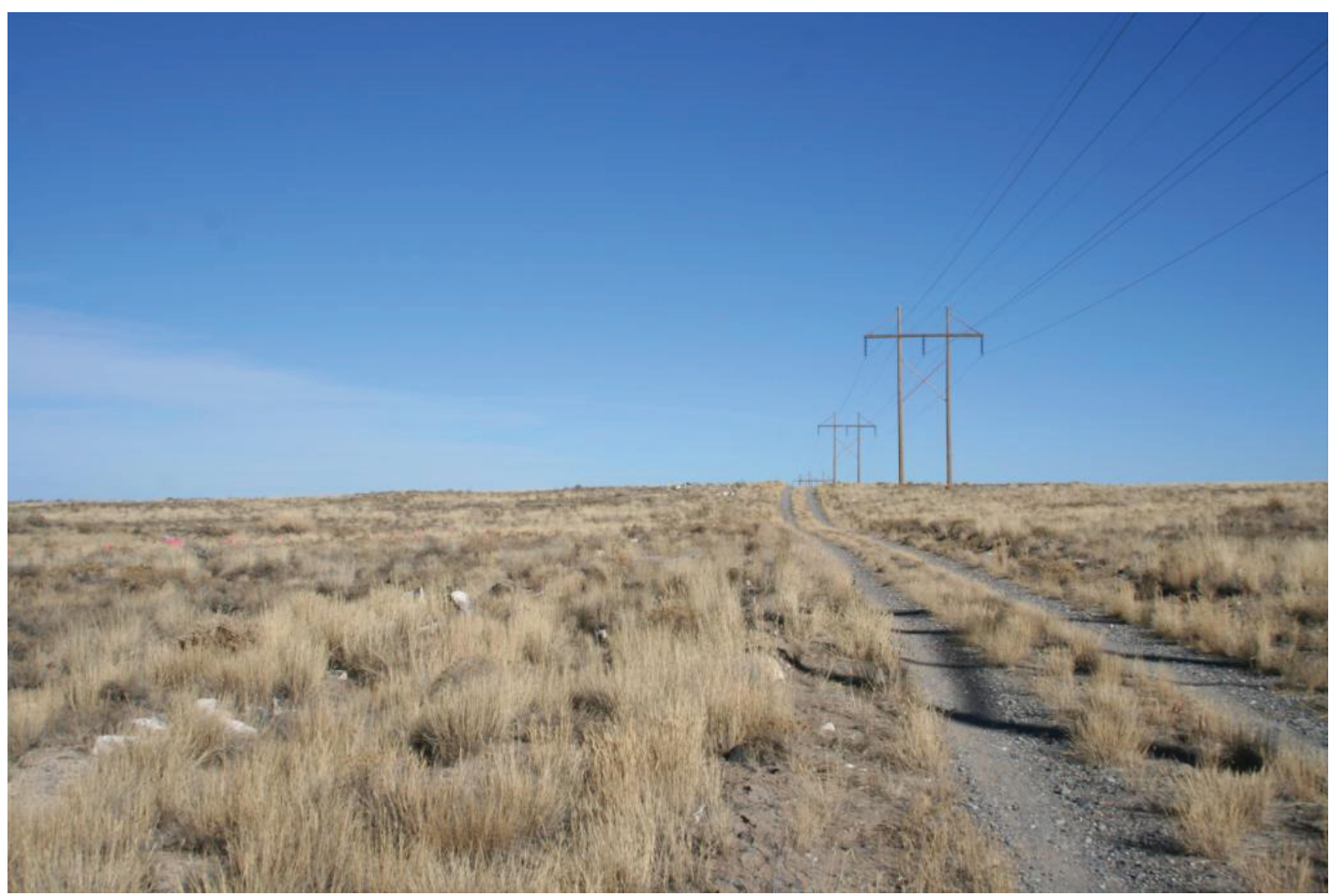

Figure 11. Facing southwest, general area of site 10-BM-112, burned between 1985 and 2005.

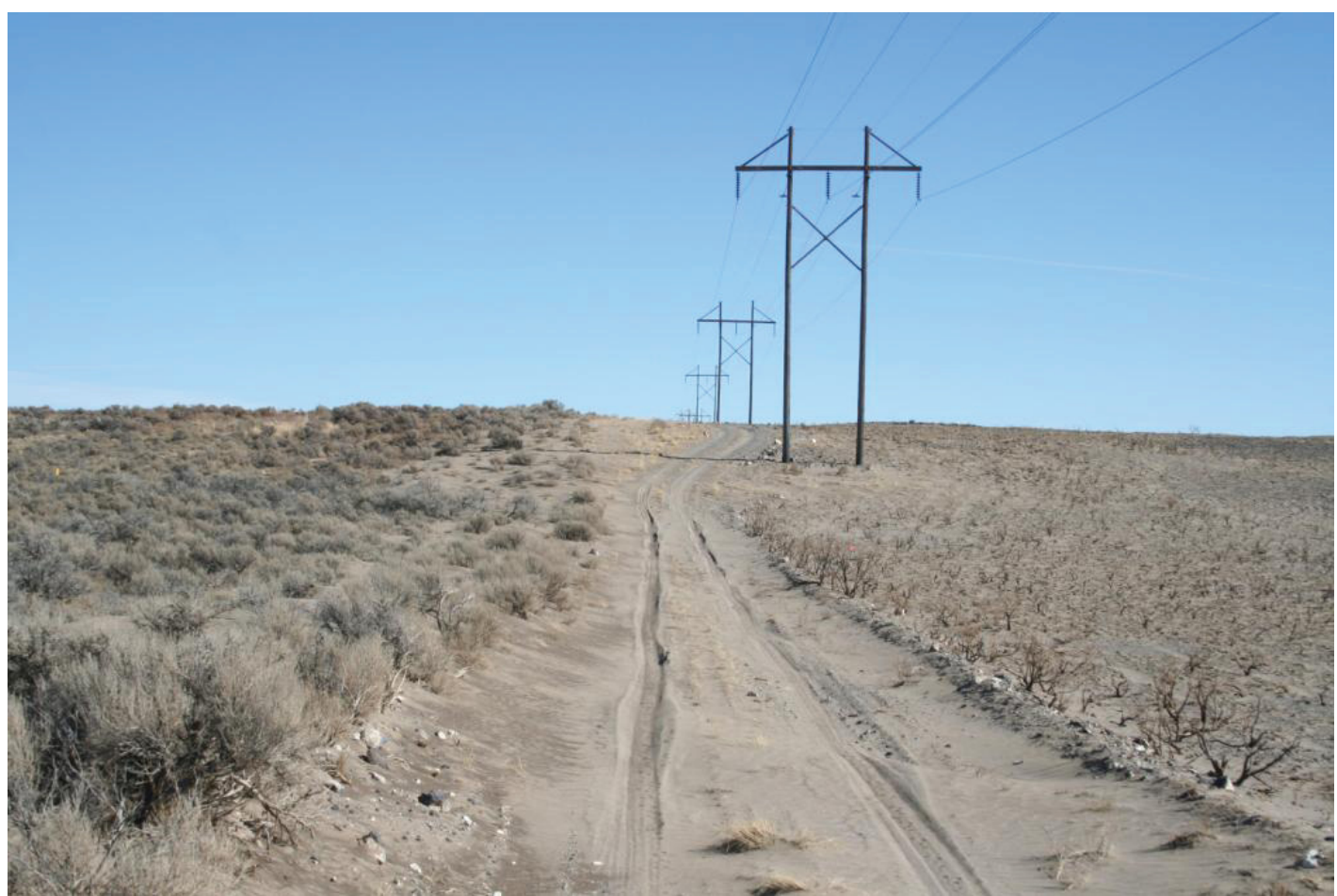

Figure 12. Facing east, general area of site 10-BT-1049, after 2008 fire and subsequent new soil deposition. 


\subsection{Evaluation of Previous Investigations}

Since 1984, archaeological surveys of INL lands have been intensive and conducted according to the standards currently outlined in the INL CRM Plan. Prior to this time, INL archaeological surveys were not necessarily intensive and documentation does not meet current standards. All of the previous surveys along the T-25 power line road and T-24 were intensive and conducted after 1984. Under the INL CRM Plan (DOE-ID 2009), areas that were intensively surveyed more than ten years ago are subject to new archaeological reconnaissance when new ground-disturbing projects are proposed there.

INL CRM policies for re-examination of previously surveyed areas help to ensure that any area proposed for new ground disturbance is intensively examined (transect interval $<20 \mathrm{~m}$ ) and that all cultural resources with visible surface remains are documented. Beginning in 2005, segments of both alternative routes have been intensively re-examined to assess various options for creating a new multipurpose haul road in the area. During these recent evaluations, all previously recorded archaeological site locations have been confirmed, with relatively little change since the original recordings. Previously recorded isolates have been more difficult to re-identify, probably due to original collection of most of the artifacts. During the new surveys, only a few new isolated artifact locations have been identified and added to the inventory. This recent field work confirms the validity and intensity of the original surveys and indicates that all National Register-eligible resources that exist in the project area have been identified. 


\section{EXPECTED HISTORIC AND PREHISTORIC LAND USE AND SITE DENSITY}

Previous archaeological investigations along the two current alternatives for construction of the multipurpose haul road and in the surrounding area provide a solid basis for anticipating the nature and extent of archaeological resources in and around the project area. Indeed, repeated surveys along the T25 power line road for various INL projects from 1988 to 2008 and revisits to many of the archaeological sites known to occur there and along T-24 provide a complete inventory of the archaeological sites present in the areas of potential effect for the current project. In addition, these investigations provide a unique record of the dynamic nature of surface soils in this area.

Although none of the archaeological sites originally recorded during intensive survey of the T-25 power line road and T-24 in 1985, 2005, and 2008 have been completely covered by loose surface soils and no new archaeological sites have been revealed through deflation, the character of the exposed surfaces do appear to have changed over the past two decades. Direct comparison of chipped stone tool artifact distributions is complicated because 1985 survey protocols involved nearly complete collection and subsequent curation of nearly all stone tools encountered. However, 1985 descriptions of the density and distributions of stone tool manufacturing debris and nondiagnostic artifacts that were not collected do often differ slightly from 2008 observations. In fact, the assemblages exposed today differ slightly from those exposed even as recently as 2008. Aside from rebar stake datum points, no evidence of the 1988 test excavation units is currently visible. These slight differences are due to the ongoing effects of fire, wind, snow melt, desiccation and cracking, and animal movement. They suggest that buried artifacts and features may be present within the boundaries of previously recorded resources, even if there are few artifacts currently exposed at the surface.

\subsection{Known or Expected Resources}

The inventory of known previously recorded cultural resources along the proposed alternatives for haul road construction south of the T-25 power line and along T-24 includes short term hunting camps, lithic scatters, and isolated artifact locations from the prehistoric period $(12,000-150$ years before present $[\mathrm{BP}]$ ). Native American human burials are also known in the CITRC area in the vicinity of the roads, although none have ever been identified within or near either of the roads. Although not formally documented at this time, other resources that are of traditional, cultural, and sacred importance to Shoshone-Bannock tribal members may also be located in the area. Archaeological resources dating to historic times $(50-150 \mathrm{BP})$ are also present in smaller numbers. The known historic inventory includes trash scatters, field scars with associated rock piles, and isolated artifacts.

Along the preferred alternative south of the power line and T-25, 23 previously recorded archaeological resources have been recorded. Along T-24, 27 archaeological resources have been previously recorded in and around the road. A listing of all of these previously recorded archaeological resources along the two roads is provided in Tables 3and 4 below. During fieldwork in 2005, 2008, and 2010, the locations of many of these resources were confirmed. In general however, few of the original isolate locations were re-identified, probably due to original collection of most of the artifacts. Additional discussion of the resources included in this existing inventory is provided in Sections 8.0 and 9.0. 
Table 3. Previously recorded archaeological resources in the preferred alternative for haul road construction south of the T-25 power line road.

\begin{tabular}{|c|c|c|}
\hline Site No. & Description & Location \\
\hline 10-BM-109 & Middle Prehistoric III $(3,500-1,300 \mathrm{BP})$ lithic scatter & Both sides of T-25 \\
\hline 10-BM-110 & Middle Prehistoric II $(5,000-3,500 \mathrm{BP})$ lithic scatter & Both sides of T-25 \\
\hline 10-BM-111 & $\begin{array}{l}\text { Elko Eared dart point fragment }(3,500-1,300 \mathrm{BP}) \text {, a biface } \\
\text { fragment, and two flakes }\end{array}$ & East of T-25 \\
\hline 10-BM-112 & $\begin{array}{l}\text { General Prehistoric ( } 12,000-150 \mathrm{BP}) \text { lithic scatter. Test } \\
\text { excavations in } 1988 \text { revealed no subsurface cultural deposits } \\
\text { within one portion of the site. }\end{array}$ & Both sides of T-25 \\
\hline 10-BM-115 & Middle Prehistoric III (3,50-1,300 BP) lithic scatter & East of T-25 \\
\hline 10-BM-118 & $\begin{array}{l}\text { Middle Prehistoric III ( } 3,500-1,300 \mathrm{BP}) \text { lithic scatter. Test } \\
\text { excavations in } 1988 \text { revealed no subsurface cultural deposits } \\
\text { within one portion of the site. }\end{array}$ & Both sides of T- 25 \\
\hline 10-BM-119 & $\begin{array}{l}\text { General Prehistoric }(12,000-150 \mathrm{BP}) \text { biface fragment and a } \\
\text { retouched flake }\end{array}$ & South of T-25 \\
\hline 10-BM-122 & General Prehistoric $(12,000-150 \mathrm{BP})$ retouched flake & South of T-25 \\
\hline $1997-16-22$ & $\begin{array}{l}\text { Dispersed scatter of historic debris (ca. 1920) including domestic } \\
\text { trash, crockery, china, milled wood, sheet metal, rubber, and misc } \\
\text { metal items probably associated with a nearby historic trail and } \\
\text { early land surveys of the region }\end{array}$ & South of T-25 \\
\hline 10-BT-1049 & $\begin{array}{l}\text { General Prehistoric }(12,000-150 \mathrm{BP}) \text { lithic scatter with stone tool } \\
\text { manufacturing debris }\end{array}$ & Both sides of T-25 \\
\hline 10-BT-1050 & General Prehistoric $(12,000-150 \mathrm{BP})$ biface fragment & South of T-25 \\
\hline 10-BT-1051 & Besant Side-notched dart point fragment $(5,000-3,500 \mathrm{BP})$ & South of T-25 \\
\hline 10-BT-1052 & $\begin{array}{l}\text { Middle Prehistoric III }(3,500-1,300 \mathrm{BP}) \text { lithic scatter. Test } \\
\text { excavations in } 1988 \text { revealed subsurface cultural deposits and a } \\
\text { hearth dated to } 310 \pm 80 \mathrm{BP} \text {. }\end{array}$ & Both sides of T-25 \\
\hline 10-BT-1053 & General Prehistoric $(12,00-150 \mathrm{BP})$ lithic scatter & South of T-25 \\
\hline 10-BT-1059 & $\begin{array}{l}\text { Late Prehistoric I (1,300-700 BP) lithic scatter. Test excavations } \\
\text { in } 1988 \text { revealed shallow subsurface cultural deposits }\end{array}$ & Both sides of T-25 \\
\hline 10-BT-1062 & General Prehistoric $(12,000-150 \mathrm{BP})$ lithic scatter & Both sides of T-25 \\
\hline 10-BT-1063 & Late Prehistoric I (1,300-700 BP) campsite & South of T-25 \\
\hline 10-BT-1159 & Elko Corner-notched dart point fragment $(3,500-1,300 \mathrm{BP})$ & South of T-25 \\
\hline 10-BT-1246 & $\begin{array}{l}\text { Two General Prehistoric }(12,000-150 \mathrm{BP}) \text { biface fragments, one } \\
\text { retouched flake, and two flakes }\end{array}$ & South of T-25 \\
\hline 10-BT-1247 & $\begin{array}{l}\text { Middle Prehistoric III }(3,500-1,300 \mathrm{BP}) \text { campsite with evidence of } \\
\text { a fire hearth. Test excavations in } 1988 \text { revealed subsurface cultural } \\
\text { deposits. }\end{array}$ & South of T-25 \\
\hline 10-BT-1248 & $\begin{array}{l}\text { Middle Prehistoric }(7,500-1,300 \mathrm{BP}) \text { dart point fragment and one } \\
\text { flake }\end{array}$ & South of T-25 \\
\hline 10-BT-1249 & Rosegate Corner-notched arrow point fragment $(1,300-700 \mathrm{BP})$ & South of T-25 \\
\hline $\begin{array}{l}\text { BEA-2006- } \\
03-03\end{array}$ & $\begin{array}{l}\text { Middle Prehistoric II }(5,000-1,300) \text { stemmed-indented base dart } \\
\text { point fragment }\end{array}$ & South of T-25 \\
\hline
\end{tabular}


Table 4. Previously recorded archaeological resources in the alternative for haul road construction along the T-24 road.

\begin{tabular}{|c|c|c|}
\hline Site No. & Description & Location \\
\hline 10-BM-106 & $\begin{array}{l}\text { General Prehistoric (12,000-150 BP) lithic scatter - potentially } \\
\text { eligible to NRHP }\end{array}$ & North of T-24 \\
\hline 10-BT-1002 & $\begin{array}{l}\text { Middle and Late Prehistoric (7,000-150 BP) lithic scatter - } \\
\text { potentially eligible to NRHP }\end{array}$ & Both sides of T-24 \\
\hline 10-BT-1003 & $\begin{array}{l}\text { General Prehistoric (12,000-150 BP) lithic scatter - potentially } \\
\text { eligible to NRHP }\end{array}$ & North of T-24 \\
\hline 10-BT-1004 & $\begin{array}{l}\text { Late Prehistoric }(1,300-150 \mathrm{BP}) \text { lithic scatter - potentially eligible } \\
\text { to NRHP }\end{array}$ & $\begin{array}{l}\text { Within and north of } \\
\text { T-24 }\end{array}$ \\
\hline 10-BT-1005 & $\begin{array}{l}\text { General Prehistoric }(12,000-150 \mathrm{BP}) \text { isolate location - not eligible } \\
\text { to NRHP }\end{array}$ & North of T-24 \\
\hline 10-BT-1006 & $\begin{array}{l}\text { Middle Prehistoric II }(5,000-1,300 \mathrm{BP}) \text { lithic scatter - potentially } \\
\text { eligible to NRHP }\end{array}$ & $\begin{array}{l}\text { Within and north of } \\
\text { T-24 }\end{array}$ \\
\hline 10-BT-1007 & $\begin{array}{l}\text { General Prehistoric }(12,000-150 \mathrm{BP}) \text { isolate location - not eligible } \\
\text { to NRHP }\end{array}$ & North of T-24 \\
\hline 10-BT-1008 & $\begin{array}{l}\text { Late Prehistoric }(1,300-150 \mathrm{BP}) \text { lithic scatter - potentially eligible } \\
\text { to NRHP }\end{array}$ & Both sides of T-24 \\
\hline 10-BT-1009 & $\begin{array}{l}\text { General Prehistoric (12,000-150 BP) lithic scatter - potentially } \\
\text { eligible to NRHP }\end{array}$ & Both sides of T-24 \\
\hline 10-BT-1013 & $\begin{array}{l}\text { Middle Prehistoric II }(5,000-3,500 \mathrm{BP}) \text { lithic scatter - potentially } \\
\text { eligible to NRHP }\end{array}$ & $\begin{array}{l}\text { Within and north of } \\
\text { T-24 }\end{array}$ \\
\hline 10-BT-1014 & $\begin{array}{l}\text { Middle Prehistoric }(7,500-3,500 \mathrm{BP}) \text { isolate location - not eligible } \\
\text { to NRHP }\end{array}$ & North of T-24 \\
\hline 10-BT-1015 & $\begin{array}{l}\text { General Prehistoric }(12,000-150 \mathrm{BP}) \text { lithic scatter associated with } \\
\text { a linear depression that is probably a collapsed lava tube - } \\
\text { potentially eligible to NRHP }\end{array}$ & $\begin{array}{l}\text { Within and north of } \\
\mathrm{T}-24\end{array}$ \\
\hline 10-BT-1016 & $\begin{array}{l}\text { General Prehistoric (12,000-150 BP) lithic scatter - potentially } \\
\text { eligible to NRHP }\end{array}$ & North of T-24 \\
\hline 10-BT-1017 & $\begin{array}{l}\text { General Prehistoric }(12,000-150 \mathrm{BP}) \text { isolate location - not eligible } \\
\text { to NRHP }\end{array}$ & North of T-24 \\
\hline 10-BT-1018 & $\begin{array}{l}\text { Middle and Late Prehistoric ( } 7,000-150 \mathrm{BP}) \text { lithic scatter - } \\
\text { potentially eligible to NRHP }\end{array}$ & Both sides of T-24 \\
\hline 10-BT-1019 & $\begin{array}{l}\text { Middle Prehistoric III }(3,500-1,300 \text { BP) isolate location - not } \\
\text { eligible to NRHP }\end{array}$ & North of T-24 \\
\hline 10-BT-1020 & $\begin{array}{l}\text { Middle Prehistoric I ( } 7,500-5,000 \text { BP) lithic scatter - potentially } \\
\text { eligible to NRHP }\end{array}$ & North of T-24 \\
\hline 10-BT-1021 & $\begin{array}{l}\text { Middle and Late Prehistoric (7,000-150 BP) campsite - potentially } \\
\text { eligible to NRHP }\end{array}$ & North of T-24 \\
\hline 10-BT-1022 & $\begin{array}{l}\text { Late Prehistoric }(1,300-150 \mathrm{BP}) \text { lithic scatter - potentially eligible } \\
\text { to NRHP }\end{array}$ & North of T-24 \\
\hline 10-BT-1023 & $\begin{array}{l}\text { General Prehistoric }(12,000-150 \mathrm{BP}) \text { isolate location - not eligible } \\
\text { to NRHP }\end{array}$ & North of T-24 \\
\hline
\end{tabular}


Table 4. continued.

\begin{tabular}{|c|c|c|}
\hline Site No. & Description & Location \\
\hline 10-BT-1024 & $\begin{array}{l}\text { General Prehistoric }(12,000-150 \mathrm{BP}) \text { isolate location - not eligible } \\
\text { to NRHP }\end{array}$ & North of T-24 \\
\hline 10-BT-1025 & $\begin{array}{l}\text { General Prehistoric (12,000-150 BP) lithic scatter - potentially } \\
\text { eligible to NRHP }\end{array}$ & $\begin{array}{l}\text { Within and north of } \\
\text { T-24 }\end{array}$ \\
\hline 10-BT-1027 & $\begin{array}{l}\text { General Prehistoric }(12,000-150 \mathrm{BP}) \text { isolate location - not eligible } \\
\text { to NRHP }\end{array}$ & North of T-24 \\
\hline $\begin{array}{l}\text { BEA-2006- } \\
03-01\end{array}$ & $\begin{array}{l}\text { General Prehistoric }(12,000-150 \mathrm{BP}) \text { isolate location - not eligible } \\
\text { to NRHP }\end{array}$ & Within T-24 \\
\hline 10-BT-1046 & $\begin{array}{l}\text { General Prehistoric (12,000-150 BP) lithic scatter - potentially } \\
\text { eligible to NRHP }\end{array}$ & $\begin{array}{l}\text { Along CITRC } \\
\text { fence }\end{array}$ \\
\hline 10-BT-1178 & $\begin{array}{l}\text { Middle Prehistoric }(7,500-1,300 \mathrm{BP}) \text { isolate location - not eligible } \\
\text { to NRHP }\end{array}$ & $\begin{array}{l}\text { Along CITRC } \\
\text { fence }\end{array}$ \\
\hline 10-BT-1121 & $\begin{array}{l}\text { Middle Prehistoric III }(3,500-1,300 \mathrm{BP}) \text { isolate location - not } \\
\text { eligible to NRHP }\end{array}$ & $\begin{array}{l}\text { Along CITRC } \\
\text { fence }\end{array}$ \\
\hline
\end{tabular}

\subsection{Known or Expected Themes, Time Periods, and INL Contexts}

The following Tables illustrate the general themes, time periods, and INL-specific contexts documented within the archaeological record in the vicinity of the proposed alternatives for haul road construction.

Table 5. General themes and time periods anticipated in the project area.

\begin{tabular}{|l|l||l|}
\hline \multicolumn{2}{|c||}{ THEMES } & \multicolumn{1}{c|}{ TIME PERIODS } \\
\hline$[\mathrm{x}]$ Archaeology & {$[$ ] Military } & {$[\mathrm{x}]$ Prehistoric } \\
\hline$[\mathrm{x}]$ Agriculture & {$[\mathrm{]}$ Mining } & {$[\mathrm{x}]$ Historic Native American } \\
\hline[] Architecture & {$[\mathrm{x}]$ Native Americans } & {$[\mathrm{x}]$ Exploration: $1805-1860$} \\
\hline[] Civilian Conservation Corps & {[] Politics/Government. } & {$[\mathrm{x}]$ Settlement: $1855-1890$} \\
\hline$[\mathrm{x}]$ Commerce & {$[\mathrm{x}]$ Public Land Management } & {$[\mathrm{x}]$ Statehood: $1890-1904$} \\
\hline[] Communication & {$[$ ] Recreation/Tourism } & {$[\mathrm{x}]$ Statehood: $1904-1920$} \\
\hline[] Culture and Society & {$[\mathrm{x}]$ Settlement } & {$[\mathrm{x}]$ Interwar: $1920-1940$} \\
\hline[] Ethnic heritage & {$[$ ] Timber } & {$[$ ] Pre-Modern: $1940-1958$} \\
\hline[] Exploration/Fur Trade & {$[\mathrm{x}]$ Transportation } & {$[$ ] Modern: $1958-$ present } \\
\hline[] Industry & {$[$ ] Other: } & \\
\hline
\end{tabular}

Table 6. INL-specific contexts anticipated in the project area.

\begin{tabular}{|l|l|l|}
\hline $\begin{array}{l}\text { [x] Prehistoric Native } \\
\text { American: } 15,000-150 \mathrm{BP}\end{array}$ & $\begin{array}{l}\text { [ ] Ordnance Testing, Naval } \\
\text { Proving Ground: } 1942-1949\end{array}$ & $\begin{array}{l}\text { [ ] Nuclear Reactor Testing, } \\
\text { Development: } 1955-1970\end{array}$ \\
\hline $\begin{array}{l}\text { [x] Historic Native American: } \\
150 \mathrm{BP}-\text { present }\end{array}$ & $\begin{array}{l}\text { [ ] Ordnance Testing, Vietnam } \\
\text { War: } 1968-1970\end{array}$ & $\begin{array}{l}\text { [ ] Post Nuclear Reactor Research: } \\
1971-\text { present }\end{array}$ \\
\hline $\begin{array}{l}\text { [x] Euro American Contact/ } \\
\text { Settlement: } 1805-1942\end{array}$ & [ ] Nuclear Reactor Testing, & $\begin{array}{l}\text { [ ] Remediation of Nuclear Waste: } \\
\text { Establishment: } 1949-1971\end{array}$ \\
\hline
\end{tabular}




\section{METHODS OF INVESTIGATION}

All work during the 2010 cultural resource investigations for the multipurpose haul road was performed in a manner consistent with formal and informal standards and guidelines issued by the Idaho SHPO, the Advisory Council on Historic Preservation, the National Park Service, and Department of Interior, as outlined in DOE-ID's CRM Plan (DOE-ID 2009).

\subsection{Field Techniques}

The field survey tactics employed during the project were designed to provide intensive visual coverage of the current ground surface to ensure that all archaeological resources with visible surface remains were identified. Intensive surveys at INL are accomplished through the use of systematic pedestrian transects with surveyors walking no more than 20 meters apart, typically in skirmish line fashion. In 2010, intensive survey efforts were focused on the preferred alternative south of the power line and T-25. Surveys were completed by a crew of three archaeologists, walking parallel to the power line in two main transects that intensively covered a $262 \mathrm{ft}(80 \mathrm{~m})$ wide zone south of the line. A handheld GPS unit with sub-meter accuracy was used to navigate to previously recorded sites, many of which had been mapped during 2008 investigations. GPS coordinates were collected to pinpoint the locations of newly identified archaeological resources and to map any newly discovered artifacts at previously recorded sites. Only limited reconnaissance at known archaeological sites and no new intensive surveys were conducted along T-24 in 2010. Fieldwork in all areas was facilitated by trouble-free access on existing roads.

In general, when cultural materials are encountered during an intensive survey transect, previous survey records, including site forms, are consulted to determine if the newly discovered artifacts are associated with a known site or isolate location. At all newly discovered artifacts, careful searches $(3-5$ meter survey intervals) are conducted to ascertain the current boundaries of the resource and to pinpoint temporally or functionally diagnostic artifacts, artifact concentrations, cultural features, or areas of postdepositional disturbance. If the newly discovered artifacts fall within or near the original boundaries of a previously recorded site or isolate, monitoring forms are completed to document the location and current condition of the resource and note any new discoveries. When single unmodified prehistoric flakes or historic cans are identified in areas where no previously recorded resources are known, notations are made on field maps and notes, but no formal site recording forms are prepared. Occurrences of $2-9$ flakes or cans or $1-9$ diagnostic artifacts in areas where no previously recorded resources are known are classified as "isolates" and are formally recorded. Formal recording is also completed for "sites" ( $\geq 10$ artifacts within 100 meters or any number of items within an active geologic setting).

During the 2010 surveys south of the power line and T-25, ten archaeological resources were newly discovered within $262 \mathrm{ft}(80 \mathrm{~m})$ of the power line. INL-tailored recording forms were completed for all of these resources and these forms are included in Appendix D. In all cases, newly found diagnostic artifacts were photographed or sketched and their relative positions were recorded with the GPS unit. No artifacts were collected for permanent curation during the 2010 surveys.

\subsection{Surface Conditions}

Sparse vegetation at INL typically provides excellent surface visibility. Recent burns along both alternatives for construction of the new multipurpose have complicated surface visibility. Erosion has occurred in some areas and in others, thick accumulations of aeolian sand have been deposited. However, overall surface visibility was excellent in most areas where approximately $70-80 \%$ of the ground was un-obscured. Sunny conditions prevailed for most of the days spent in the field. 


\subsection{Areas Not Examined}

No new intensive archaeological surveys were completed along the T-24 alternative. However, previously recorded sites confirmed to be within the roadway in 2005 were revisited and a tour of the road was provided for tribal representatives from the Shoshone-Bannock Heritage Tribal Office.

\subsection{Native American Involvement}

INL complies with and follows federal and state laws and regulations, DOE policies, and INLspecific management plans that define how DOE and its contractors will interact with Native Americans. More specifically, DOE-ID recognizes its trust responsibility to the Shoshone-Bannock Tribes, whose aboriginal lands include the INL. In the spirit of that responsibility, DOE-ID has entered into an Agreement in Principle (AIP) with the Tribes (DOE-ID 2007). In addition to defining a broad range of interests and working relationships, the AIP devotes particular attention to the management of INL cultural resources. Broadly, its intent is to foster confidence on the part of the Shoshone-Bannock Tribes that INL cultural resources are managed in a spirit of protection and stewardship. To achieve this, the AIP provides for routine tribal participation in new and ongoing INL projects with an open invitation to comment on, visit, observe, and/or assist in cultural resource management investigations.

Per the guidelines established in the INL Cultural Resource Management Plan and the spirit of the Agreement in Principle, tribal representatives have been included in discussions and information exchanges on the haul road project since its inception early in 2010 and have participated in two site visits on April 20, 2010 and May 26, 2010. DOE-ID also presented information on the project to the ShoshoneBannock Tribal Council in April of 2010. Tribal representatives will continue to be provided with opportunities to participate in future planning and implementation of archaeological surveys, impact assessments, and protection strategies for cultural resources identified in the project area.

\subsection{Field Personnel}

All field work during the 2010 investigation was conducted by INL CRM Office personnel: Brenda Pace, Julie Braun Williams, Clayton Marler, Hollie Gilbert, Cameron Brizzee, and Dino Lowrey. Carolyn Smith, LaRae Bucksin, and Anthony Bagley from the Shoshone-Bannock Tribes participated in the tribal tours conducted by Clayton Marler.

\subsection{Dates of Fieldwork}

Fieldwork was conducted in April, May, and June of 2010.

\subsection{Problems Encountered}

No problems were encountered. 


\section{RESULTS}

In 2010, a new intensive archaeological survey was conducted in the preferred alternative for construction of the new multipurpose haul road within a $262 \mathrm{ft}(80 \mathrm{~m})$ wide corridor south of the power line and T-25 and in expanded zones at corner points where sharp corners may need to be smoothed during later construction. Approximately 341 acres were examined in this survey (Figures 4 - 6). No new intensive surveys were completed along road T-24 in 2010, although previously recorded sites documented within the roadway during 2005 investigations were revisited.

Fieldwork in the preferred alternative south of the power line and T-5 resulted in the documentation of eight new isolated artifact locations, one new lithic scatter, and one new historic debris scatter. The locations of many previously recorded resources were also confirmed in 2010, including two previously recorded isolate locations, where chipped stone artifacts were not subject to complete collection in 1985, as well as 13 previously recorded archaeological sites. Artifact assemblages currently exposed at these localities differ slightly from the original recordings, particularly in areas that have burned. In some burned areas, sand dunes have accumulated over some archaeological sites, obscuring artifacts from view. In other burned areas, winds have scoured the ground surface and the resulting lack of vegetation revealed larger assemblages than noted originally. In spite of the changes in artifact visibility, all previously recorded resources remain visible on the landscape and retain the same essential components originally recorded in their assemblages.

Specific Native American cultural resources were not officially documented by the ShoshoneBannock Tribes in either of the alternate routes for haul road construction. However, tribal representatives from the Shoshone-Bannock Tribes' Heritage Tribal Office participated in intensive surveys of the T-25 power line road and T-24 in 2005 and toured both routes in 2010, visiting the larger prehistoric sites located there. Information on the multipurpose haul road construction project was also presented to tribal representatives at regular 2010 Cultural Resource Working Group meetings in February, March, May, and June and DOE-ID met with the Tribal Council to discuss the project in April. Over time, tribal representatives have continued to express general concerns in regard to protection of prehistoric archaeological sites as well as elements of the natural environment that may be impacted.

Additional information on the resources confirmed to be within the boundaries of the two alternatives for haul road construction is provided in the Sections to follow. INL CRM site recording forms and monitoring forms with detailed documentation are provided in Appendix D and all of the resources are plotted on maps in Appendix C. Legal restrictions on the distribution of sensitive information detailing the exact location of archaeological resources may result in the removal of these Appendices from some versions of this report.

\subsection{Resources Identified}

No new surveys were conducted along the T-24 alternative in 2010 and it is assumed that all 27 of the previously recorded resources listed in Table 4 (Section 6.1) may be within the area of potential effects for this alternative. In 2005, nine of the resources listed in Table 4 were confirmed to be exposed within the T-24 roadbed, including: 10-BT-1018, 10-BT-1015, 10-BT-1025, 10-BT-1004, 10-BT-1002, 10-BT1008, 10-BT-1009, 10-BT-1013, and 10-BT-1006 (Pace et al. 2005:21). All of these resources were revisited in 2010, but no new artifacts were inventoried.

New intensive surveys of the preferred alternative for haul road construction south of the power line and T-25 were concentrated in a $262 \mathrm{ft}(80 \mathrm{~m})$ wide corridor south of the power line. Intensive surveys in this corridor resulted in the documentation of eight new isolated artifact locations, one new lithic scatter, one new historic debris scatter, two previously recorded isolate locations, and 13 previously recorded archaeological sites. All of these newly and previously recorded resources are described in Table 7, arranged in order of occurrence from west to east. Maps in Appendix C illustrate the locations of these resources and site recording and monitoring forms with additional detail are provided in Appendix D. 
The potential effects of haul road construction and recommended protective measures are summarized in Section 9 of the report.

Table 7. Archaeological resources recorded in the preferred alternative for haul road construction south of the $\mathrm{T}-25$ power line road.

\begin{tabular}{|c|c|c|}
\hline Site No. & Description & Location \\
\hline BEA-2010-11-04 & $\begin{array}{l}\text { Isolated artifact: newly recorded Middle Prehistoric III }(3,500- \\
1,300 \mathrm{BP}) \text { Elko Corner-notched point fragment. }\end{array}$ & South of T-25 \\
\hline BEA-2010-11-03 & $\begin{array}{l}\text { Isolated artifact: newly recorded General Prehistoric }(12,000-150 \\
\text { BP) biface midsection. }\end{array}$ & South of T-25 \\
\hline 10-BT-1159 & $\begin{array}{l}\text { Isolated artifact: previously recorded Middle Prehistoric }(7,500- \\
1,300 \mathrm{BP}) \text { large notched point fragment re-identified in } 2010 \text {. }\end{array}$ & South of T-25 \\
\hline 10-BT-1059 & $\begin{array}{l}\text { Lithic Scatter: Late Prehistoric I (1,300-700 BP) - originally } \\
\text { recorded as a scatter of } 35 \text { flakes with a large corner-notched point } \\
\text { and biface fragments. Test excavation of two 1x } 2 \text { m units in } 1988 \\
\text { confirmed shallow subsurface cultural deposits. In } 2008 \text { a chaining } \\
\text { pin from the testing was re-identified along with } 20 \text { flakes, an Elko } \\
\text { Corner-notched point, and a biface fragment. In } 2010 \text { these } \\
\text { artifacts could not be re-identified, but the scatter of } 20 \text { flakes } \\
\text { beneath the power line was confirmed. }\end{array}$ & $\begin{array}{l}\text { Both sides of } \\
\mathrm{T}-25\end{array}$ \\
\hline 10-BT-1062 & $\begin{array}{l}\text { Lithic Scatter: General Prehistoric }(12,000-150 \mathrm{BP}) \text { - originally } \\
\text { recorded as a thin scatter of } 18 \text { flakes and a scraper. Range fires in } \\
2008 \text { exposed many more flakes, totaling nearly } 100 \text {, along with an } \\
\text { Elko corner-notched point, Humboldt Lanceolate point, biface } \\
\text { fragments, and a scraper. In } 2010 \text {, this site was confirmed to be } \\
\text { located to the north of the haul road project area. }\end{array}$ & $\begin{array}{l}\text { Both sides of } \\
\mathrm{T}-25\end{array}$ \\
\hline 10-BT-1063 & $\begin{array}{l}\text { Campsite: Late Prehistoric I ( } 1,300-700 \mathrm{BP}) \text { - originally recorded } \\
\text { as a thin widely dispersed scatter of seven flakes, a large corner- } \\
\text { notched point and a river cobble, possibly fire-cracked. In } 2008 \\
\text { wind erosion after a range fire had exposed } 30 \text { flakes and a large } \\
\text { notched point fragment } 50 \mathrm{~m} \text { south of the power line. No artifacts } \\
\text { were observed in the } 2010 \text { survey area south of the power line. }\end{array}$ & South of T-25 \\
\hline BEA-2010-11-06 & $\begin{array}{l}\text { Isolated artifacts: newly recorded General Prehistoric }(12,000-150 \\
\text { BP) scatter of nine flakes. }\end{array}$ & South of T-25 \\
\hline 10-BM-109 & $\begin{array}{l}\text { Lithic Scatter: Middle Prehistoric III }(3,500-1,300 \mathrm{BP}) \text { - originally } \\
\text { recorded as } 71 \text { widely scattered flakes and seven biface fragments. } \\
\text { In } 2008,60 \text { flakes, two biface fragments, and two scrapers were } \\
\text { observed. In } 2010 \text {, this site was confirmed to be concentrated to } \\
\text { the north of the haul road project area. }\end{array}$ & $\begin{array}{l}\text { Both sides of } \\
\text { T-25 }\end{array}$ \\
\hline BEA-2010-11-07 & $\begin{array}{l}\text { Lithic Scatter: newly recorded General Prehistoric }(12,000-150 \\
\text { BP) scatter of } 60 \text { flakes with one biface fragment and a utilized } \\
\text { flake within the survey area south of the power line. }\end{array}$ & South of T-25 \\
\hline BEA-2010-11-08 & $\begin{array}{l}\text { Isolated artifact: newly recorded Historic (1917) brass cap survey } \\
\text { marker }\end{array}$ & South of T-25 \\
\hline
\end{tabular}


Table 7. continued.

\begin{tabular}{|c|c|c|}
\hline Site No. & Description & Location \\
\hline 10-BT-1049 & $\begin{array}{l}\text { Lithic Scatter: General Prehistoric }(12,000-150 \mathrm{BP}) \text { - originally } \\
\text { recorded as a light scatter of } 13 \text { flakes and a stemmed point } \\
\text { fragment. In } 2008 \text {, significant erosion after a range fire had } \\
\text { deposited deep aeolian sand over all but a few of the original } \\
\text { artifacts north of T-25. In } 2010 \text {, additional artifacts, including a } \\
\text { scatter of } 50 \text { flakes, an obsidian core, fire-cracked basalt fragments, } \\
\text { a Bitterroot Side-notched point fragment, nondiagnostic point } \\
\text { fragment, and biface tip were observed in the survey area south of } \\
\text { the power line. }\end{array}$ & $\begin{array}{l}\text { Both sides of } \\
\mathrm{T}-25\end{array}$ \\
\hline BEA-2010-11-10 & $\begin{array}{l}\text { Isolated artifacts: newly recorded Late Prehistoric I (1,300-700 } \\
\text { BP) Desert Side-notched point fragment, biface tip, and utilized } \\
\text { flake. }\end{array}$ & South of T-25 \\
\hline BEA-2010-11-11 & $\begin{array}{l}\text { Isolated artifact: newly recorded General Prehistoric }(12,000-150 \\
\text { BP) biface tip. }\end{array}$ & South of T-25 \\
\hline 10-BT-1053 & $\begin{array}{l}\text { Lithic Scatter: General Prehistoric }(12,000-150 \mathrm{BP}) \text { - originally } \\
\text { recorded as a widely dispersed scatter of } 27 \text { flakes. Fire breaks } \\
\text { were cut through the site in } 2008 \text { and flakes were exposed, } \\
\text { particularly in the densest concentration of artifacts approximately } \\
80 \text { meters south of the power line, but also two flakes near the T- } 25 \\
\text { road. In } 2010 \text { artifacts were observed outside the survey area far to } \\
\text { the south of the power line, but no artifacts were observed in the } \\
\text { haul road project area. }\end{array}$ & South of T-25 \\
\hline 10-BT-1247 & $\begin{array}{l}\text { Campsite: Middle Prehistoric III }(3,500-1,300 \mathrm{BP}) \text { - originally } \\
\text { recorded as a small scatter of } 30 \text { flakes, a large notched point } \\
\text { fragment and a biface fragment. In } 1988 \text { test excavation of one } 1 \times 2 \\
\text { m unit confirmed shallow subsurface cultural deposits. In } 2008 \text {, a } \\
\text { rebar stake from the test excavation was identified along with a } \\
\text { light scatter of } 25 \text { flakes and two Elko Corner-notched points. A } \\
\text { light scatter of } 10 \text { flakes was observed in the } 2010 \text { survey area } \\
\text { south of the power line. }\end{array}$ & South of T-25 \\
\hline 10-BT-1246 & $\begin{array}{l}\text { Isolated artifacts: previously recorded General Prehistoric } \\
(12,000-150 \mathrm{BP}) \text { biface fragments and a retouched flake. In } 2010 \text {, } \\
\text { the retouched flake was re-identified. }\end{array}$ & South of T-25 \\
\hline 10-BT-1052 & $\begin{array}{l}\text { Lithic Scatter: Middle Prehistoric III }(3,500-1,300 \mathrm{BP}) \text { - originally } \\
\text { recorded as a scatter of } 60 \text { flakes in two concentrations with three } \\
\text { large notched points, a Cottonwood Triangular fragment, and } \\
\text { utilized flakes. Test excavation of five } 1 \times 2 \mathrm{~m} \text { test pits and } \\
\text { additional } 1 \mathrm{x} 1 \mathrm{~m} \text { units in } 1988 \text { confirmed shallow subsurface } \\
\text { cultural deposits and a hearth dated to } 310 \pm 80 \mathrm{BP} \text {. In } 2005 \text {, two } \\
\text { additional large notched fragments, two Desert Side-notched Sierra } \\
\text { fragments, and a piece of shell were discovered. In } 2008 \text {, these } \\
\text { artifacts could not be re-identified, but a stemmed-indented base } \\
\text { fragment and two utilized flakes were noted. In } 2010 \text { a light scatter } \\
\text { of flakes was observed in the survey area south of the power line. }\end{array}$ & $\begin{array}{l}\text { Both sides of } \\
\mathrm{T}-25\end{array}$ \\
\hline
\end{tabular}


Table 7. continued.

\begin{tabular}{|c|c|c|}
\hline Site No. & Description & Location \\
\hline BEA-2010-11-01 & $\begin{array}{l}\text { Debris Scatter: newly recorded Historic (ca. } 1917-1925) \text { scatter } \\
\text { of nine cans and a broken bottle in the survey area south of the } \\
\text { power line. }\end{array}$ & South of T-25 \\
\hline BEA-2010-11-02 & $\begin{array}{l}\text { Isolated artifact: newly recorded Middle Prehistoric II (5,000 - } \\
1,300 \mathrm{BP}) \text { stemmed-indented base dart point fragment. }\end{array}$ & South of T-25 \\
\hline LMIT-1997-16-22 & $\begin{array}{l}\text { Debris Scatter: Historic (ca. 1920) - originally recorded as light } \\
\text { scatter of domestic debris. Original observations confirmed in } \\
2010 \text { with various cans, glass shards, china fragments, possible car } \\
\text { parts, milled wood and other metal noted to the south of the haul } \\
\text { road project area. }\end{array}$ & South of T-25 \\
\hline 10-BM-118 & $\begin{array}{l}\text { Lithic Scatter: Middle Prehistoric III }(3,500-1,300 \mathrm{BP}) \text { - original } \\
\text { recording of a small scatter of } 50 \text { flakes and several biface } \\
\text { fragments. Test excavation of one } 1 \times 2 \text { m pit in } 1988 \text { revealed no } \\
\text { significant cultural deposits. In } 2005 \text {, one large point fragment was } \\
\text { observed, but in } 2008 \text { only } 15 \text { flakes were visible. No artifacts } \\
\text { were observed in the } 2010 \text { survey area south of the power line. }\end{array}$ & $\begin{array}{l}\text { Both sides of } \\
\mathrm{T}-25\end{array}$ \\
\hline 10-BM-115 & $\begin{array}{l}\text { Lithic Scatter: Middle Prehistoric III ( } 3,500-1,300 \mathrm{BP}) \text { - original } \\
\text { recording of a concentrated scatter of } 15 \text { flakes, an Elko Corner- } \\
\text { notched point fragment, and several biface fragments. In } 2008 \text {, } \\
\text { only } 11 \text { flakes were observed more than } 50 \text { meters from the power } \\
\text { line. No artifacts were observed in } 2010 \text { survey area south of the } \\
\text { power line. }\end{array}$ & East of T-25 \\
\hline 10-BM-112 & $\begin{array}{l}\text { Lithic Scatter: General Prehistoric }(12,000-150 \mathrm{BP}) \text { - original } \\
\text { recording of a thin scatter of } 10 \text { flakes. Shovel probe in } 1988 \\
\text { revealed no significant cultural deposits. In } 2005 \text {, two biface } \\
\text { fragments were observed and in } 2008,15 \text { flakes and two burned } \\
\text { bone fragments were observed. Artifacts observed in } 2008 \text { were } \\
\text { confirmed in the } 2010 \text { survey area east of the power line. }\end{array}$ & East of T-25 \\
\hline 10-BM-110 & $\begin{array}{l}\text { Lithic Scatter: Middle Prehistoric ( } 7,500-1,300 \mathrm{BP}) \text { - original } \\
\text { recording of a widely dispersed scatter of } 80 \text { flakes, fragmentary } \\
\text { dart points, and biface fragments. In } 2008,50 \text { flakes and one } \\
\text { retouched flake were observed along with evidence of unauthorized } \\
\text { surface collection (potter's pile). No artifacts were observed in the } \\
2010 \text { survey area south of the power line. }\end{array}$ & $\begin{array}{l}\text { Both sides of } \\
\mathrm{T}-25\end{array}$ \\
\hline BEA-2010-11-13 & $\begin{array}{l}\text { Isolated artifact: newly recorded Middle Prehistoric II }(5,000 \text { - } \\
3,500 \text { BP) stemmed-indented base point. }\end{array}$ & $\begin{array}{l}\text { Near Taylor } \\
\text { Blvd }\end{array}$ \\
\hline
\end{tabular}

\subsection{Resources Noted But Not Recorded}

All archaeological materials observed within the $262 \mathrm{ft}(80 \mathrm{~m})$ wide corridor south of the power line were formally recorded by completion of INL-tailored site recording forms or site monitoring forms for previously recorded sites. Based on tribal involvement in the 2005, 2008, and 2010 fieldwork, it is likely that contemporary Native American resource values are also present, but the Shoshone-Bannock Tribes have not pinpointed any of these resources at this time. General tribal concerns regarding impacts to archaeological sites and natural resources (e.g. plants and animals) have been noted. 


\subsection{Summary of Important Characteristics of Identified Resources}

All of the archaeological resources identified within the two alternatives for haul road construction contribute to the overall base of knowledge of prehistoric and historic use of the northeastern Snake River Plain. Appendix D contains site recording and/or monitoring forms for each of the resources identified and Appendix $\mathrm{C}$ provides detailed locational information.

Numerous isolated artifact locations are represented in the inventory, including seven newly recorded prehistoric locations and one historic location: BEA-2010-11-04, BEA-2010-11-03, BEA-2010-11-06, BEA-2010-11-08 (historic), BEA-2010-11-10, BEA-2010-11-11, BEA-2010-11-02, and BEA-2010-1113 , as well as two previously recorded locations: 10BT-1246 and 10-BT-1159. The prehistoric localities range from light scatters of less than ten unmodified flakes to fragmentary projectile point fragments. All probably reflect light, hunting-related use of the Big Lost River vicinity during the Prehistoric period from approximately 12,000 - 150 years BP. Finds like this are common across the high desert lands of the INL. They represent short-term activities by the hunter-gatherers who lived here at this time and are unlikely to yield any information beyond that which was collected during the initial field recording. The historic marker reflects early historic land surveys of the region and is also unlikely to yield any additional information. Site recording and monitoring forms included in Appendix D and maps in Appendix C provide additional detail on these resources.

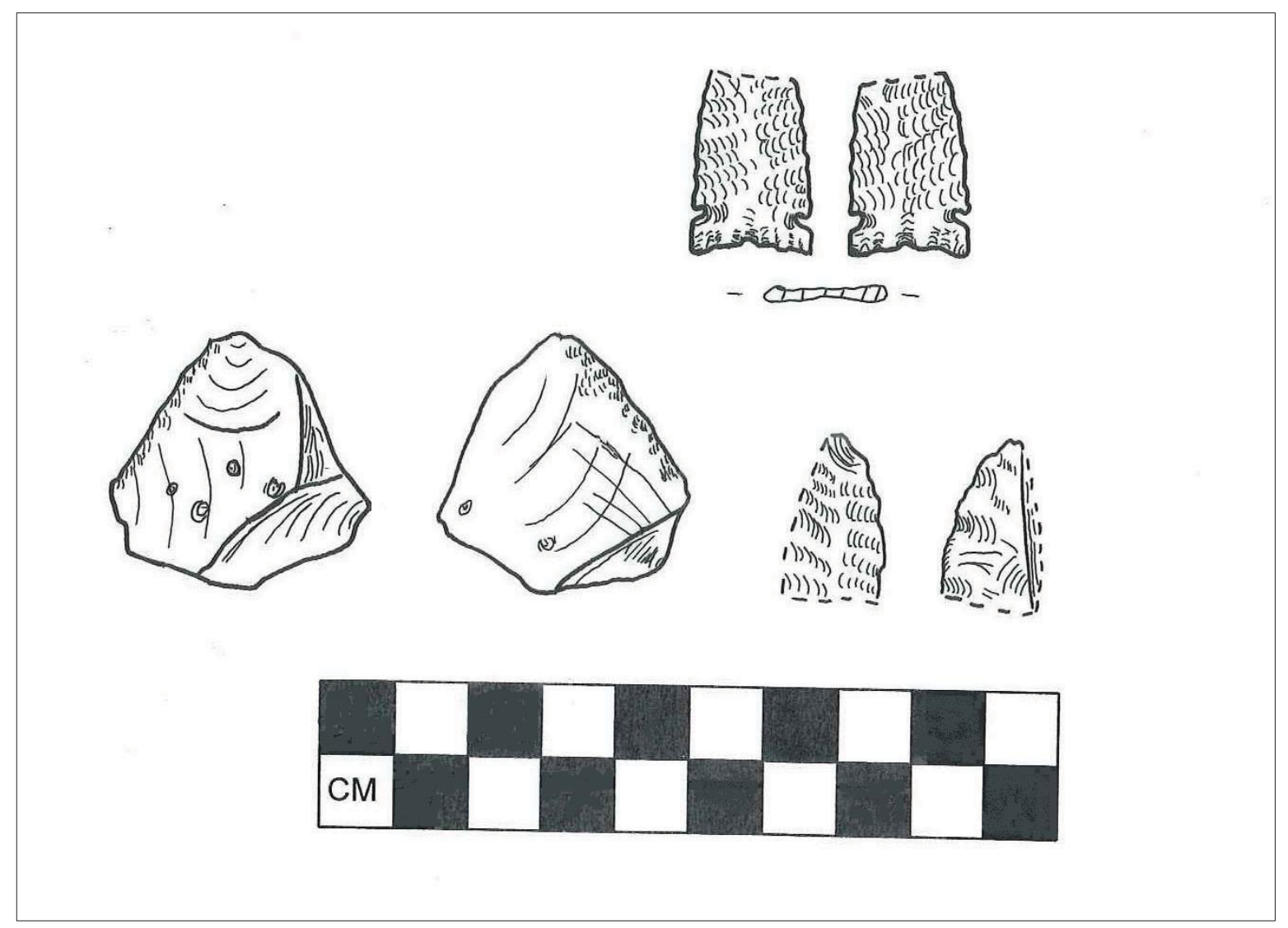

Figure 13. Typical isolated artifacts discovered in the preferred alternative for haul road construction south of the T-25 power line road (BEA-2010-11-10). 
The larger prehistoric lithic scatters and campsites recorded south of the power line and T-25 reflect more intensive prehistoric activities. Only one new locality was discovered during the 2010 survey within the $262 \mathrm{ft}(80 \mathrm{~m})$ corridor (BEA-2010-11-07). This site is located in a recently burned zone near previously recorded site 10-BT-1049, where wind erosion after a 2008 range fire has exposed new artifacts south of the power line and covered artifacts to the north.

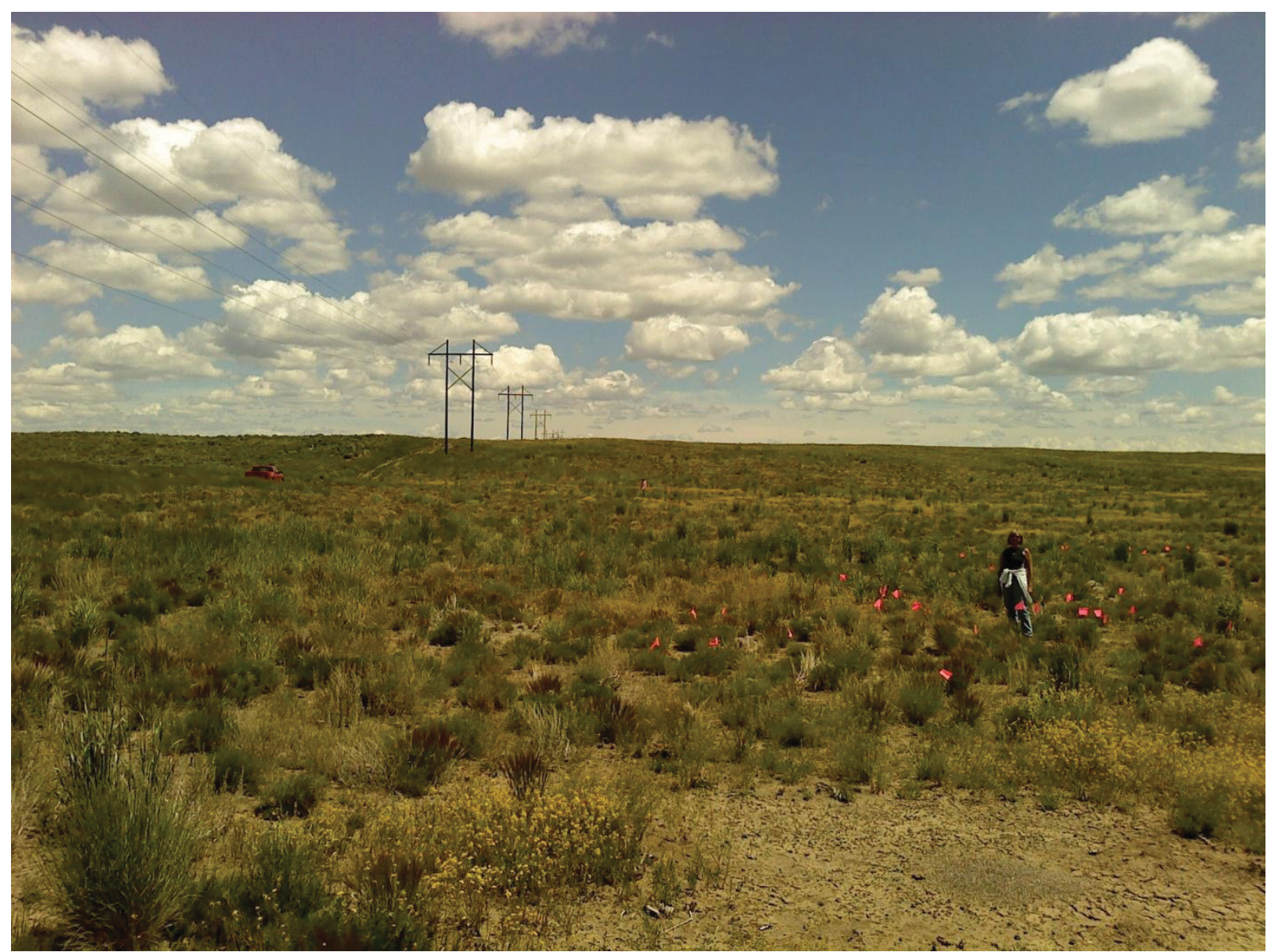

Figure 14. Archaeological sites BEA-2010-11-07 (foreground) and 10-BT-1049 (distant background) are located in an area where wind erosion has exposed many artifacts.

The majority of the archaeological sites confirmed to be located south of the power line and T-25 are previously recorded sites (10-BT-1059, 10-BT-1062, 10-BT-1063, 10-BM-109, 10-BT-1049, 10-BT1053, 10-BT-1247, 10-BT-1052, LMIT-1997-16-22, 10-BM-118, 10-BM-115, 10-BM-112, 10-BM-110). In 1988, test excavations were conducted at five of the prehistoric sites in this inventory (10-BM-112, 10 BM-118, 10-BT-1052, 10-BT-1247, and 10-BT-1059) to evaluate cultural deposits in an area of potential effects associated with maintenance of the power line (Ringe 1988). Subsurface cultural deposits were identified at three of these prehistoric campsites (10-BT-1052, 10-BT-1247, and 10-BT-1059) during these investigations, confirming National Register eligibility (Ringe 1988, Green 1989). Two of the small prehistoric lithic scatters subject to testing (10-BM-112 and 10-BM-118) revealed no subsurface materials and were determined to be ineligible for nomination to the National Register (Ringe 1988, Green 1989).

It is likely that unevaluated subsurface cultural materials may also be present at the remaining untested archaeological sites or even at tested sites in areas that have not been previously excavated. During investigations in 2005, 2008, and 2010, new diagnostic artifacts have been identified at several of these previously recorded sites. Additional detail on these resources and the artifacts found are included in Appendices C and D. 
The majority of the prehistoric archaeological sites identified south of T-25 and the power line do exhibit potential to yield additional information. These resources are characterized by scatters of stone flakes created during the maintenance and manufacture of stone tools, as well as a variety of chipped stone tools including projectile points, biface fragments, and utilized flakes used to hunt and process game and other resources. Aeolian processes are actively re-working soils at several of these locations and several have revealed evidence of subsurface cultural features (i.e. fire hearths), indicative of more intensive camping and processing activities. All retain relatively good integrity and may contain additional information, possibly including buried cultural deposits, as evidenced by previous test excavations (Ringe 1988) and the discovery of new diagnostic artifacts within their boundaries during the 2005, 2008, and 2010 surveys.

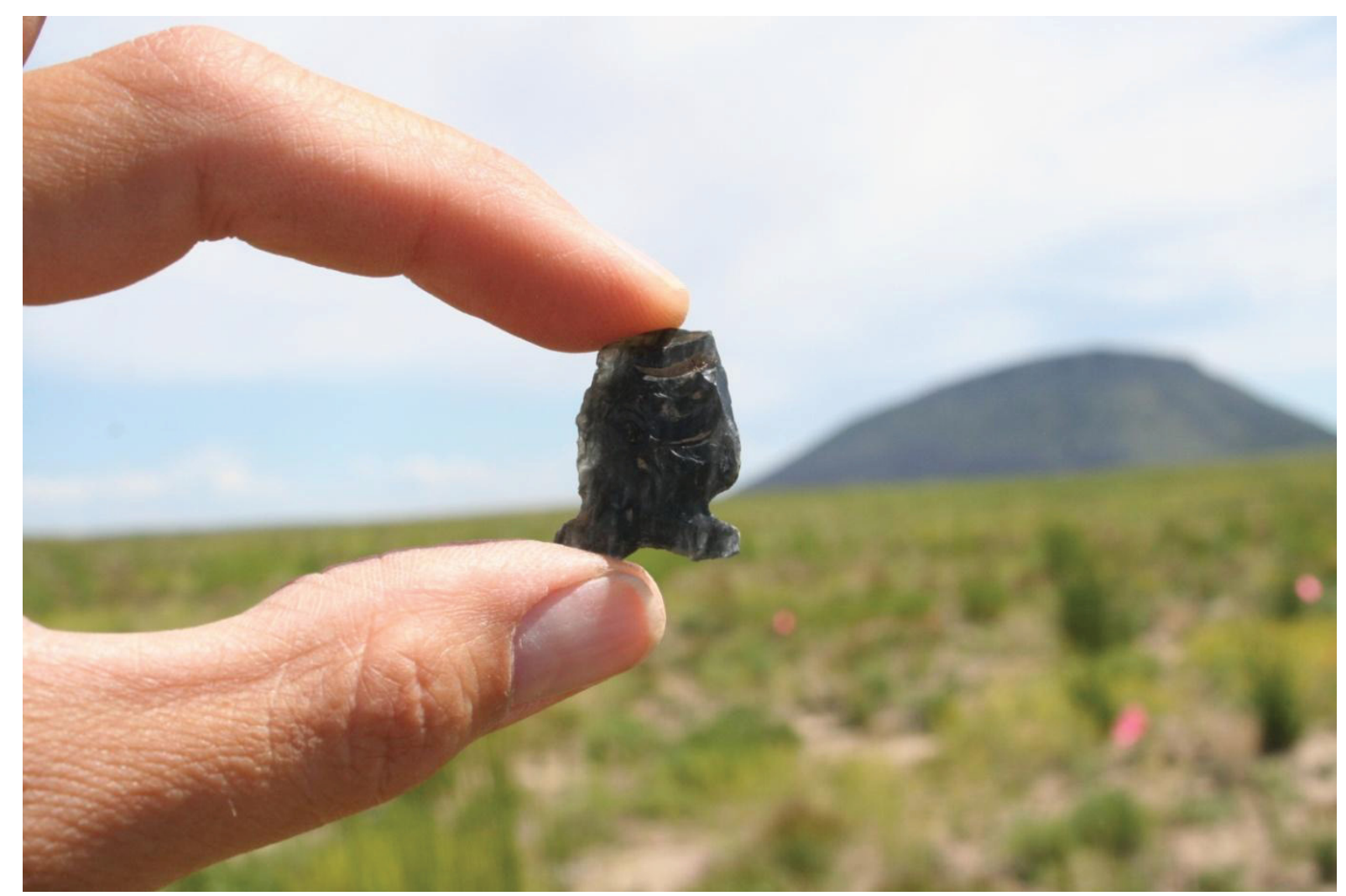

Figure 15. Newly discovered large side-notched point fragment from 10-BT-1049.

Historic archaeological sites are rare along the proposed alternatives for haul road construction associated with T-25 and T-24. Archival research conducted in 2008 by INL historian, Hollie Gilbert, indicates that the T-25 power line road passes through a number of agricultural field scars and homestead claims from the early 1900s (Pace 2008:25). The historic debris scatters indentified south of the power line road may be associated with these early settlement efforts or it is possible that they were created slightly later, during early land surveys in the 1910s and 1920s. The location of both sites near an older two-track trail and the artifacts identified within the assemblages suggest that they predate INL-related surveys and development. Only one of the identified sites, LMIT-1997-16-22, exhibits any potential for yielding additional information.

Specific Native American cultural resources within the area of potential effect and values associated with natural resources in the area will need to be identified and described through interaction and/or formal consultation with the Shoshone-Bannock Tribes. INL lands are included within the aboriginal homeland of the Tribes and it is anticipated that tribal concerns will center on natural resources and 
prehistoric archaeological sites, which continue to fill important roles in tribal heritage and ongoing cultural traditions.

\subsection{National Register Eligibility}

Additional investigations will be necessary to develop National Register eligibility assessments for archaeological resources located along T-24. As a result, until proven ineligible, all 27 of the previously recorded resources (Table 4, Section 6.1) located along T-24 are considered potentially eligible for nomination.

With new intensive surveys and field evaluations conducted in 2005, 2008, and 2010, it is possible to provide more precise evaluations for resources identified in the preferred alternative for haul road construction south of the power line and T-25. In the preferred alternative the ten identified isolated artifact locations are unlikely to yield any additional information important in the study of prehistory or early history and are therefore considered to be ineligible. This applies to the two isolates recorded during previous surveys, but re-identified in 2010 (10-BT-1246 and 10-BT-1159) as well as the following newly recorded isolates: BEA-2010-11-04, BEA-2010-11-03, BEA-2010-11-06, BEA-2010-11-08, BEA2010-11-10, BEA-2010-11-11, BEA-2010-11-02, and BEA-2010-11-13.

Similarly, the newly recorded small scatter of historic cans and glass (BEA-2010-11-01) located in the preferred alternative is also unlikely to yield additional information and is recommended as ineligible for nomination to the National Register. However, the larger scatter of historic debris (LMIT-1997-1622) exhibits a wider range of artifact types and may represent a broader range of historic activities. Additional information may be gleaned from analysis of some of the artifacts present in this assemblage and the site is evaluated as potentially eligible for nomination to the National Register based on this information potential (criterion "d" of 36 CFR Part 60).

Eleven of the thirteen prehistoric campsites and lithic scatters recorded south of the power line and T25 in the preferred alternative for haul road construction are considered to be potentially eligible for nomination to the National Register under criterion "d" of 36 CFR Part 60 (10-BT-1059, 10-BT-1062, 10BT-1063, 10-BM-109, 10-BT-1049, 10-BT-1053, 10-BT-1247, 10-BT-1052, 10-BM-115, 10-BM-110, and one newly recorded site, BEA-2010-11-07). The significance of all of these sites is measured by their research potential; all are suspected of containing important subsurface cultural deposits accessible only through systematic archaeological excavation and intensive surface survey. At three locations, subsurface cultural deposits have already been confirmed through test excavations in 1988 (10-BT-1052, 10-BT1247, and 10-BT-1059) (Ringe 1988, Green 1989). Because the subsurface cultural deposits at these locations are fragile and shallowly buried, equipment movement, vehicle traffic, and even heavy pedestrian traffic can easily disturb them. Precautionary measures must be implemented to ensure that they are not adversely impacted by road upgrade activities.

The two small prehistoric lithic scatters tested in 1988 and determined ineligible for nomination to the National Register because of a lack of subsurface cultural deposits (10-BM-112, 10-BM-118) (Ringe 1988, Green 1989) must also be re-evaluated in light of proposed plans. However, it is considered unlikely that these resources will yield any additional materials of significance. 


\section{CONCLUSIONS AND RECOMMENDATIONS}

The discussion to follow provides a synthesis of identified resources, potential impacts, and recommendations for avoiding adverse cultural resource impacts during construction within the preferred alternative for haul road construction south of the power line and T-25. Additional cultural resource investigations will be necessary to develop similar recommendations for cultural resource assessment and protection if the T-24 alternative is selected.

\subsection{Summary of Investigations}

Cultural resource investigations completed in 2010 to determine the potential impacts of construction of a new multipurpose haul road were focused on the preferred alternative for construction south of the power line and T-25. Archive searches, intensive archaeological field surveys, and coordination with the Shoshone-Bannock Tribes were completed for this area. Cultural resource investigations of the other alternative route along T-24 were less intensive; involving short revisits to previously recorded archaeological sites known to be located within the existing roadway and a tour for representatives from the Shoshone-Bannock Tribes.

Along the preferred alternative south of the power line and T-25, 341 acres were surveyed in a $262 \mathrm{ft}$ $(80 \mathrm{~m})$ wide corridor south of the power line and in two expanded zones where sharp corners will likely require some smoothing (Figures 4 - 6). The intensive surveys resulted in the recording or re-evaluation of 25 archaeological resources. Appendix D contains INL site recording and monitoring forms with additional detail on the identified resources and exact locations are plotted on maps in Appendix C.

Nearly half of the resources identified in the preferred alternative south of T-25 are isolated artifacts or very small artifact scatters including nine prehistoric artifact locations, one historic land survey marker, and one small historic debris scatter. None of these 11 resources are evaluated as eligible for nomination to the National Register of Historic Places. This includes eight isolates newly recorded in 2010 (BEA2010-11-04, BEA-2010-11-03, BEA-2010-11-06, BEA-2010-11-08, BEA-2010-11-10, BEA-2010-11-11, BEA-2010-11-02, and BEA-2010-11-13), two isolates originally recorded in 1985 and re-identified in 2010 (10-BT-1246 and 10-BT-1159), and one small scatter of historic debris newly recorded in 2010 (BEA-2010-11-01). These provide important information on broad patterns of prehistoric and historic human use of the region. However they are unlikely to yield any additional information.

The remaining 14 resources in the preferred alternative south of T-25 are larger archaeological sites that exhibit potential for buried cultural deposits and/or additional information, possibly including datable cultural features. Twelve are evaluated as potentially eligible to the National Register as a result (10-BT1059, 10-BT-1062, 10-BT-1063, 10-BM-109, 10-BT-1049, 10-BT-1053, 10-BT-1247, 10-BT-1052, LMIT-1997-16-22, 10-BM-115, 10-BM-110, and BEA-2010-11-07). In fact, test excavations in 1988 confirmed the presence of buried materials at three of these prehistoric campsites (10-BT-1052, 10-BT1247, and 10-BT-1059). Also included in the total is one larger historic site that may be restricted to a surface context (LMIT-1997-216-22), but is evaluated as potentially eligible for the information potential exhibited by the artifact assemblage that it contains. Finally, two prehistoric lithic scatters tested in 1988 and determined to have no significant subsurface cultural deposits (10-BM-112 and 10-BM-118) are being evaluated again in light of proposed plans, although it is unlikely that they will yield any additional information.

Although no Native American cultural resources have been specifically identified within either of the proposed alternatives for haul road construction, representatives from the Shoshone-Bannock Tribes have indicated that prehistoric archaeological sites and native plants and animals across the INL area are of tribal importance. 


\subsection{Potential Threats to Identified Resources}

Ground disturbance associated with the construction of a new multipurpose haul road will be intensive and has the potential to impact any archaeological sites and natural resources of importance to the Shoshone-Bannock Tribes in the proposed road center line. In addition to direct impacts from heavy equipment and earth-moving, archaeological sites and Native American resources identified in the area could also be subject to indirect impacts during construction as a result of higher visibility on the landscape and overall increases in activity levels in a previously undeveloped area. Artifacts may be subject to unauthorized collection or impacted by unauthorized off-road vehicle use. Resident and migratory birds and animals may be disturbed and noxious and invasive weeds may increase.

All of these activities could jeopardize the integrity of archaeological and Native American resources in the route that is ultimately chosen for construction. A final assessment of impacts will not be possible until project plans are finalized. However, it is possible at this time to outline general measures that can be implemented to prevent adverse impacts to the resources that have been identified in the preferred alternative for construction south of the power line and T-25.

\subsection{Relationship of Identified Resources to Project Impacts}

Table 8 below lists all cultural resources identified in the preferred alternative for haul road construction south of the power line and T-25 and indicates the relationship of each resource to anticipated project impacts. Recommendations to protect resources from adverse impacts during construction are also included. Maps in Appendix C illustrate the specific locations of identified cultural resources in relation to the proposed road centerline and area of potential effects, which is estimated at 30 $\mathrm{ft}$ in width on average at this time

No effects are anticipated at isolated artifacts or small artifact scatters, which are evaluated as ineligible for nomination to the National Register. This includes: BEA-2010-11-04, BEA-2010-11-03, BEA-2010-11-06, BEA-2010-11-08, BEA-2010-11-10, BEA-2010-11-11, BEA-2010-11-02, BEA-201011-13, 10-BT-1246, 10-BT-1159, and BEA-2010-11-01.

Field surveys confirmed that several of the identified archaeological sites that are potentially eligible for nomination to the National Register are located near, but outside the proposed road center line and monitoring is recommended for these areas to ensure that direct impacts are avoided (10-BT-1062, 10BT-1063, LMIT-1997-16-22, 10-BM-115, and 10-BM-110). At three archaeological sites only a few isolated artifacts are located in or near the proposed road centerline, with the bulk of sensitive cultural material located outside. Monitoring is also recommended for these locations (10-BT-1059, 10-BM-109, and 10-BT-1053). At the two sites previously tested and evaluated as ineligible for nomination to the National Register as a result (10-BM-112 and 10-BM-118), construction monitoring is also recommended.

Direct construction impacts will be unavoidable at four resources that are eligible or potentially eligible for nomination to the National Register. This includes: BEA-2010-11-07, 10-BT-1049, 10-BT1247, and 10-BT-1052. Test excavations are recommended for these resources to determine if significant subsurface deposits are present in the area of potential effects for road construction.

Following standards established in the INL CRM Plan (DOE-ID 2009: Appendix C), the test excavations will be guided by the practical objective of determining the nature and extent of any buried cultural deposits to assess future research potential and establish National Register eligibility. Future research potential will be evaluated in light of general research questions included in Appendix E of the INL CRM Plan. Test pits will be $1 \times 1 \mathrm{~m}$ or $1 \times 2 \mathrm{~m}$ in size and placed intuitively within the proposed road centerline. Excavation will proceed in $10 \mathrm{~cm}$ levels or according to stratigraphic layers and will extend to the maximum anticipated depth of disturbance for the haul road project (estimated at $40 \mathrm{~cm}$ on 
average) or to at least $10 \mathrm{~cm}$ below the last artifact-bearing level. Bedrock basalt may also limit the depth of test excavations.

All soils excavated from test pits will be screened through 1/8 inch hardware mesh and recovered artifacts will be logged, bagged, and collected with careful notation of horizontal and vertical provenience. Various field samples may also be recovered during excavation, depending on the materials encountered (pollen, charcoal, bulk soil, etc.). When excavation is complete, measured profiles and photographs will be completed for all test units and the holes will be backfilled. All artifacts, samples, and records assembled during the test excavation will be submitted for permanent curation at the Southeastern Idaho Regional Archaeological Center located in the Idaho Museum of Natural History on the Idaho State University campus in Pocatello, Idaho.

Table 8. Relationship of identified resources in the preferred alternative for haul road construction south of the power line and T-25 to anticipated project impacts and recommended protection measures.

\begin{tabular}{|c|c|c|c|}
\hline Site No. & $\begin{array}{l}\text { National Register } \\
\text { Eligibility }\end{array}$ & Anticipated Impacts & $\begin{array}{l}\text { Recommended } \\
\text { Protection } \\
\text { Measure(s) } \\
\end{array}$ \\
\hline BEA-2010-11-04 & Isolate location - not eligible & No effect. & No further work \\
\hline BEA-2010-11-03 & Isolate location - not eligible & No effect. & No further work \\
\hline 10-BT-1159 & Isolate location - not eligible & No effect. & No further work \\
\hline 10-BT-1059 & $\begin{array}{l}\text { National Register-eligible } \\
\text { prehistoric lithic scatter with } \\
\text { confirmed shallow } \\
\text { subsurface deposits }\end{array}$ & $\begin{array}{l}\text { Direct impacts but } \\
\text { proposed road center line } \\
\text { passes through southern } \\
\text { edge of site where } \\
\text { artifacts are rare. No } \\
\text { artifacts were observed in } \\
\text { road center line in } 2010 .\end{array}$ & $\begin{array}{l}\text { Monitor for new } \\
\text { finds during ground } \\
\text { disturbance }\end{array}$ \\
\hline 10-BT-1062 & $\begin{array}{l}\text { Lithic scatter - potentially } \\
\text { eligible for information } \\
\text { potential }\end{array}$ & $\begin{array}{l}\text { No direct impacts; site is } \\
\text { north of proposed road } \\
\text { center line. }\end{array}$ & $\begin{array}{l}\text { Monitor for new } \\
\text { finds during ground } \\
\text { disturbance }\end{array}$ \\
\hline 10-BT-1063 & $\begin{array}{l}\text { Lithic scatter - potentially } \\
\text { eligible for information } \\
\text { potential }\end{array}$ & $\begin{array}{l}\text { No direct impacts; site is } \\
\text { south of proposed road } \\
\text { center line. }\end{array}$ & $\begin{array}{l}\text { Monitor for new } \\
\text { finds during ground } \\
\text { disturbance }\end{array}$ \\
\hline BEA-2010-11-06 & Isolate location - not eligible & No effect. & No further work \\
\hline 10-BM-109 & $\begin{array}{l}\text { Lithic scatter-potentially } \\
\text { eligible for information } \\
\text { potential }\end{array}$ & $\begin{array}{l}\text { Direct impacts but } \\
\text { proposed road center line } \\
\text { passes through southern } \\
\text { edge of site where } \\
\text { artifacts are rare. No } \\
\text { artifacts were observed in } \\
\text { road center line in } 2010 .\end{array}$ & $\begin{array}{l}\text { Monitor for new } \\
\text { finds during ground } \\
\text { disturbance }\end{array}$ \\
\hline BEA-2010-11-07 & $\begin{array}{l}\text { Lithic scatter - potentially } \\
\text { eligible for information } \\
\text { potential }\end{array}$ & $\begin{array}{l}\text { Direct impacts - proposed } \\
\text { road center line passes } \\
\text { through site. }\end{array}$ & $\begin{array}{l}\text { Complete test } \\
\text { excavation of one } \\
1 \times 1 \mathrm{~m} \text { test unit in } \\
\text { proposed road } \\
\text { center line }\end{array}$ \\
\hline BEA-2010-11-08 & $\begin{array}{l}\text { Historic brass cap survey } \\
\text { marker (1917) - not eligible }\end{array}$ & No effect. & No further work \\
\hline
\end{tabular}


Table 8. continued

\begin{tabular}{|c|c|c|c|}
\hline Site No. & $\begin{array}{l}\text { National Register } \\
\text { Eligibility }\end{array}$ & Anticipated Impacts & $\begin{array}{l}\text { Recommended } \\
\text { Protection } \\
\text { Measure(s) } \\
\end{array}$ \\
\hline 10-BT-1049 & $\begin{array}{l}\text { Prehistoric campsite - } \\
\text { potentially eligible for } \\
\text { information potential }\end{array}$ & $\begin{array}{l}\text { Direct impacts - proposed } \\
\text { road center line passes } \\
\text { through site. }\end{array}$ & $\begin{array}{l}\text { Complete test } \\
\text { excavation of two } \\
1 \times 1 \mathrm{~m} \text { test units in } \\
\text { proposed road } \\
\text { center line }\end{array}$ \\
\hline BEA-2010-11-10 & Isolate location - not eligible & No effect. & No further work \\
\hline BEA-2010-11-11 & Isolate location - not eligible & No effect. & No further work \\
\hline 10-BT-1053 & $\begin{array}{l}\text { Lithic scatter - potentially } \\
\text { eligible for information } \\
\text { potential }\end{array}$ & $\begin{array}{l}\text { Direct impacts but } \\
\text { proposed road center line } \\
\text { passes through northern } \\
\text { edge of site where } \\
\text { artifacts are rare. No } \\
\text { artifacts were observed in } \\
\text { road center line in } 2010 .\end{array}$ & $\begin{array}{l}\text { Monitor for new } \\
\text { finds during ground } \\
\text { disturbance }\end{array}$ \\
\hline 10-BT-1247 & $\begin{array}{l}\text { National Register-eligible } \\
\text { prehistoric campsite with } \\
\text { confirmed shallow } \\
\text { subsurface cultural deposits }\end{array}$ & $\begin{array}{l}\text { Direct impacts - proposed } \\
\text { road center line passes } \\
\text { through site. }\end{array}$ & $\begin{array}{l}\text { Complete test } \\
\text { excavation of one } \\
1 \times 1 \mathrm{~m} \text { unit in } \\
\text { proposed road } \\
\text { center line }\end{array}$ \\
\hline 10-BT-1246 & Isolate location - not eligible & No effect. & No further work \\
\hline 10-BT-1052 & $\begin{array}{l}\text { National Register-eligible } \\
\text { prehistoric campsite with } \\
\text { confirmed shallow } \\
\text { subsurface cultural deposits } \\
\text { and a hearth dated to } 310 \pm \\
80 \text { BP }\end{array}$ & $\begin{array}{l}\text { Direct impacts - proposed } \\
\text { road center line passes } \\
\text { through site. }\end{array}$ & $\begin{array}{l}\text { Complete test } \\
\text { excavation of three } \\
1 \times 1 \mathrm{~m} \text { units in } \\
\text { proposed road } \\
\text { center line }\end{array}$ \\
\hline BEA-2010-11-01 & $\begin{array}{l}\text { Historic debris scatter - not } \\
\text { eligible }\end{array}$ & No effect. & No further work \\
\hline BEA-2010-11-02 & Isolate location - not eligible & No effect. & No further work \\
\hline LMIT-1997-16-22 & $\begin{array}{l}\text { Historic debris scatter - } \\
\text { potentially eligible for } \\
\text { information potential }\end{array}$ & $\begin{array}{l}\text { No direct impacts; site is } \\
\text { south of proposed road } \\
\text { center line. }\end{array}$ & $\begin{array}{l}\text { Monitor for new } \\
\text { finds during ground } \\
\text { disturbance and } \\
\text { complete artifact } \\
\text { collection if needed }\end{array}$ \\
\hline 10-BM-118 & $\begin{array}{l}\text { Lithic scatter - evaluated as } \\
\text { ineligible in } 1988 \text { when } 1 \mathrm{x} \\
2 \mathrm{~m} \text { test unit revealed no } \\
\text { significant cultural deposits }\end{array}$ & $\begin{array}{l}\text { No direct impacts; site is } \\
\text { north of proposed road } \\
\text { center line. }\end{array}$ & $\begin{array}{l}\text { Monitor for new } \\
\text { finds during ground } \\
\text { disturbance }\end{array}$ \\
\hline 10-BM-115 & $\begin{array}{l}\text { Lithic scatter-potentially } \\
\text { eligible for information } \\
\text { potential }\end{array}$ & $\begin{array}{l}\text { No direct impacts; site is } \\
\text { east of proposed road } \\
\text { center line. }\end{array}$ & $\begin{array}{l}\text { Monitor for new } \\
\text { finds during ground } \\
\text { disturbance }\end{array}$ \\
\hline
\end{tabular}


Table 8. Continued.

\begin{tabular}{|l|l|l|l|}
\hline \multicolumn{1}{|c|}{ Site No. } & \multicolumn{1}{|c|}{$\begin{array}{c}\text { National Register } \\
\text { Eligibility }\end{array}$} & \multicolumn{1}{c|}{ Anticipated Impacts } & \multicolumn{1}{c|}{$\begin{array}{c}\text { Recommended } \\
\text { Protection } \\
\text { Measure(s) }\end{array}$} \\
\hline $10-$ BM-112 & $\begin{array}{l}\text { Lithic scatter - evaluated as } \\
\text { ineligible in 1988 when } \\
\text { shovel probe revealed no } \\
\text { significant cultural deposits }\end{array}$ & $\begin{array}{l}\text { Direct impacts - proposed } \\
\text { road center line passes } \\
\text { through site. }\end{array}$ & $\begin{array}{l}\text { Monitor for new } \\
\text { finds during ground } \\
\text { disturbance }\end{array}$ \\
\hline $10-$ BM-110 & $\begin{array}{l}\text { Lithic scatter - potentially } \\
\text { eligible for information } \\
\text { potential }\end{array}$ & $\begin{array}{l}\text { No direct impacts; site is } \\
\text { west of proposed road } \\
\text { center line. }\end{array}$ & $\begin{array}{l}\text { Monitor for new } \\
\text { finds during ground } \\
\text { disturbance }\end{array}$ \\
\hline BEA-2010-11-13 & Isolate location - not eligible & No effect. & No further work \\
\hline
\end{tabular}

\subsection{Recommendations for Additional Investigations or Protective Measures}

Adverse effects to cultural resources in the preferred location for construction of the new multipurpose haul road south of the power line and T-25 can be minimized by implementing the testing and monitoring recommendations provided above in Table 7 . Test excavations must occur before the initiation of any ground disturbance, but after construction plans have been finalized and the exact area of potential effect, both horizontally and vertically is determined. If significant cultural deposits are uncovered during the test excavations, additional investigation may be necessary to salvage any sensitive materials before they are adversely impacted by construction. All test excavation must be conducted in consultation with the Idaho SHPO and no work can begin until this consultation is initiated.

Communication and cooperation should also continue with the Shoshone-Bannock Tribes to determine if there are additional Native American cultural resources that will need to be considered during the road construction. Formal government-to-government consultation between the Shoshone-Bannock Tribal Business Council and DOE-ID may also be necessary. Consultation with the SHPO and Tribes may also result in additional requirements to ensure that no cultural resources are adversely affected by the proposed project.

In addition to the test excavations and monitoring outlined in Table 7, several broad activities must also be initiated to minimize cultural resource impacts, including:

- Initiate consultation with the Idaho State Historic Preservation Office and implement recommendations if provided;

- Continue communication and coordination with the Shoshone-Bannock Tribes and implement recommendations if provided;

- Initiate close coordination between the INL CRM Office and project engineers to specifically identify impacts associated with the road upgrade on the ground (straightening, leveling, drainage channels, etc.) and particularly within the boundaries of the resources listed in Table 7 to facilitate the recommended cultural resource monitoring and test excavations;

- Conduct cultural resource sensitivity training for project personnel to discourage unauthorized artifact collection, off-road vehicle use, and other activities that may impact cultural resources and encourage a sense of stewardship for cultural resources, including tribally sensitive plants and animals;

- Complete test excavations at select resources that cannot be avoided by ground disturbing activities to determine if significant deposits are present; 
- Expand archaeological survey coverage and resource assessments in any new project areas that are outside the $262 \mathrm{ft}(80 \mathrm{~m}$ ) wide area surveyed for cultural resources in 2010 (e.g., equipment staging areas, borrow sources and stockpiles, equipment turnarounds, etc.);

- Conduct cultural resource monitoring of ground disturbance in sensitive areas with authority to temporarily redirect work to salvage any sensitive materials uncovered;

- Minimize disturbance to plant and wildlife species important to the Shoshone-Bannock Tribes by possible implementation of seasonal and time of day restrictions on ground disturbance, good housekeeping, and/or revegetation of disturbed areas with native plant species;

- Implement a Stop Work Procedure to guide the assessment and protection of any unanticipated discoveries of cultural materials during construction. 


\section{REPOSITORY}

Upon completion of the project, all documentation (i.e. site recording forms, photographs, reports, field notes, etc.) will be curated at the Southeastern Idaho Regional Archaeological Center located in the Idaho Museum of Natural History on the Idaho State University campus in Pocatello, Idaho.

Comprehensive permanent archives are also maintained at the INL CRM Office in Idaho Falls, ID. In the interim between field collection and permanent curation, all materials are kept in secure temporary storage at the INL CRM Office in Idaho Falls, Idaho. 


\section{REFERENCES}

Arrowrock Group Inc., 1997, The Idaho National Engineering and Environmental Laboratory: A Historical Context and Assessment, Narrative and Inventory, INEEL/EXT-97-01021, September 1997.

DOE-ID, 2007, Agreement-in-Principle (between the Shoshone-Bannock Tribes and the U.S. Department of Energy), December 2007.

DOE-ID, 2009, Idaho National Laboratory Cultural Resource Management Plan, DOE/ID-10997, Rev. 3, February 2009.

DOE-ID, 2010, Draft Environmental Assessment for the Multipurpose Haul Road Within the Idaho National Laboratory Site, DOE/EA-1772, May 2010.

Green, Thomas J. (Deputy State Historic Preservation Officer), 1989, Letter to G. C. Bowman (DOE-ID Environmental Protection Division), May 8, 1989, RE: Preliminary Report, Archaeological Test Investigations PBF and EBR II [135 kV Line].

Holmer, R. N., S. R. Plager, Brenda R. Pace, and T. Grieve, 2002, A GIS Predictive Model of Archaeological Sites in Eastern Idaho, $28^{\text {th }}$ Great Basin Anthropological Conference, Elko, NV, October 2002.

INL CRM Archives, 1997a, Project File LMIT-97-16: Partnership for Natural Disasters Test Range, Idaho Falls, ID.

INL CRM Archives, 1997b, Project File LMIT-97-49: ANL-PBF Powerline Road Maintenance, Idaho Falls, ID.

INL CRM Archives, 2008a, Project File BEA-08-09: Powerline Testing, Idaho Falls, ID.

INL CRM Archives, 2008b, Project File BEA-08-25: July 9 Fire, Idaho Falls, ID.

Idaho State Historic Preservation Office, 1995, "Idaho Archaeological and Historical Survey Manual: Guidelines for Identifying and Evaluating Cultural Properties," Historic Preservation Series No. 8, Boise, ID.

Irving, J. S., editor, 1993, Environmental Resource Document for the Idaho National Engineering Laboratory, EGG-WMO-10279, July 1993.

Miller, S. J., 1994, Report on the Human Skeletal Remains Recovered at the Power Burst Facility (PBF), Idaho National Engineering Laboratory, EGG-CS-11519, September 1994.

Miller, S. J., 1997, The WERF/SPERT III Human Skeleton, Idaho National Engineering and Environmental Laboratory, INL CRM Archives, Project File LMIT-96-27, October 1996.

Pace, Brenda Ringe, 2008, Archaeological Investigation of the East Loop Power Line Road (T-25) Upgrade on the Idaho National Laboratory, INL/EXT-08-15039, November 2008.

Pace, Brenda Ringe., C. F. Marler, H. Gilbert, D. Lowrey, and J. Braun, 2005, Cultural Resource Assessment of the Power Line Road and T-24 at the Idaho National Laboratory, INL/EXT-05-01033, December 2005.

Ringe, Brenda L., 1988, Test Excavation of Ten Sites Along the Powerline Between PBF and EBR-II, Idaho National Engineering Laboratory, Swanson/Crabtree Anthropological Research Laboratory Letter Report No. 88-6, INL CRM Archives, Project File ISU-88-6.

Ringe, Brenda, 1995, Locational Analysis and Preliminary Predictive Model for Prehistoric Cultural Resources on the Idaho National Engineering Laboratory, MA thesis, Department of Anthropology, Idaho State University, Pocatello, ID. 
Reed, W. G., J. W. Ross, B. Ringe, and R. N. Holmer, 1987, “Archaeological Investigations on the Idaho National Engineering Laboratory: 1984-1985, Revised Edition," Swanson/Crabtree Anthropological Research Laboratory Reports of Investigations: 87-1, Pocatello, ID.

Stacey, S. M., 2000, Proving the Principle: a History of the Idaho National Engineering and Environmental Laboratory 1949 - 1999, DOE-ID/10799, December 2000. 
Appendix A: Key Information 
INTENTIONALLY BLANK 


\section{Appendix A: Key Information}

A. Project name: Multipurpose Haul Road

B. Project number: INL CRM Office BEA-2010-11

C. Agency name: Battelle Energy Alliance INL CRM Office for the Department of Energy Idaho Operations Office

D. Report authors: Brenda R. Pace, Cameron Brizzee, Hollie Gilbert, Clayton Marler, Julie Braun Williams, Dino Lowrey,

E. Principal Investigator: Brenda R. Pace

F. Report date: August 2010

G. County: Butte and Bingham Counties

H. Legal locations and Project/Survey Acreage:

\begin{tabular}{|c|c|c|}
\hline ALTERNATIVE & AREA OF POTENTIAL EFFECT & $\begin{array}{l}\text { ARCHAEOLOGICAL } \\
\text { SURVEY COVERAGE }\end{array}$ \\
\hline $\begin{array}{l}\text { Preferred Alternative } \\
\text { (south of T-25) }\end{array}$ & $\begin{array}{l}\text { Corridor south of power line and T-25: } 36.36 \\
\text { acres ( } \sim 10 \text { miles long, } 30 \mathrm{ft} \text { wide) } \\
\text { Cutoff to Filmore Blvd.: } 1.45 \text { acres }(\sim 0.4 \\
\text { mile long, } 30 \mathrm{ft} \text { wide) }\end{array}$ & $\begin{array}{l}\quad \text { New intensive survey of } \\
\qquad 341 \text { acres } \\
\text { (10.4 miles long, } 262 \mathrm{ft}[80 \mathrm{~m}] \\
\text { wide plus additional acreage at } \\
\text { corners) }\end{array}$ \\
\hline $\mathrm{T}-24$ & $\begin{array}{l}\text { Existing two-track trail: } 36.65 \text { acres ( } 10 \text { miles } \\
\text { long, } 30 \mathrm{ft} \text { wide) } \\
\text { Cutoff along CITRC fence: } 4.25 \text { acres }(\sim 1.17 \\
\text { miles long, } 30 \mathrm{ft} \text { wide) }\end{array}$ & $\begin{array}{l}\text { Previous intensive survey of } \\
523 \text { acres } \\
\text { (11.25 mile long, } 328 \mathrm{ft}[100 \\
\text { m] wide })\end{array}$ \\
\hline
\end{tabular}


INTENTIONALLY BLANK 


\section{Appendix B: Certification of Results}


INTENTIONALLY BLANK 


\section{Appendix B: Certification of Results}

\section{CERTIFICATION OF RESULTS:}

I certify that this investigation was conducted and documented according to Secretary of Interior's Standards and Guidelines and that this report is complete and accurate to the best of my knowledge.

(original signed by Brenda R. Pace)

Signature of Principal Investigator

Date 
INTENTIONALLY BLANK 


\section{Appendix C: Project Maps}


INTENTIONALLY BLANK 


\section{Appendix C: Project Maps}

Appendix C contains project maps that show the specific locations of cultural resources. However, only those resources located in the archaeological survey corridors associated with the two alternatives for construction of the multipurpose haul road are shown. These alternatives are: the preferred alternative south of the power line and T-25 and a second alternative centered on road T-24.

The locational information presented in these maps is distributed for Official Use Only and may have been removed from some versions of the document. It is exempted from the Freedom of Information Act under Section 9 of the Archaeological Resources Protection Act of 1979 (as amended) and under Section 304 of the National Historic Preservation Act of 1966 (as amended). Distribution of any cultural resource locational information from this document and particularly from this Appendix must be approved in advance by contacting the INL CRM Office, PO Box 1625-2105, Idaho Falls, ID 83415, telephone: (208) 526-0916. The following maps are included here:

Map 1: Proposed road center line, new archaeological survey coverage, and identified archaeological sites in the western end of the preferred alternative for haul road construction south of the power line and $\mathrm{T}-25$.

Map 2: Proposed road center line, new archaeological survey coverage, and identified archaeological sites in the central portion of the preferred alternative for haul road construction south of the power line and T-25.

Map 3: Proposed road center line, new archaeological survey coverage, and identified archaeological resources in the eastern end of the preferred alternative for haul road construction south of the power line and $\mathrm{T}-25$.

Map 4: Proposed road center line, previous archaeological survey coverage, and previously identified archaeological sites in the western end of the T-24 alternative for haul road construction.

Map 5: Proposed road center line, previous archaeological survey coverage, and previously identified archaeological sites in the middle portion of the T-24 alternative for haul road construction.

Map 6: Proposed road center line, previous archaeological survey coverage, and previously identified archaeological sites in the eastern end of the T-24 alternative for haul road construction. 
INTENTIONALLY BLANK 
Official Use Only Figure removed 
Official Use Only Figure removed. 
Official Use Only Figure removed 
Official Use Only Figure removed 
Official Use Only Figure removed 
Official Use Only Figure removed. 
Appendix D: Site Recording and Monitoring Forms 
INTENTIONALLY BLANK 


\section{Appendix D: Site Recording and Monitoring Forms}

The locational information presented in these forms is distributed for Official Use Only and may have been removed from some versions of the document. It is exempted from the Freedom of Information Act under Section 9 of the Archaeological Resources Protection Act of 1979 (as amended) and under Section 304 of the National Historic Preservation Act of 1966 (as amended). Distribution of any cultural resource locational information from this document and particularly from this Appendix must be approved in

advance by contacting the INL CRM Office, PO Box 1625-2105, Idaho Falls, ID 83415, telephone: (208) 526-0916.

The following forms are included here:

- Isolated Find Records for BEA-2010-11-04, BEA-2010-11-03, BEA-2010-11-06, BEA-2010-11-08, BEA-2010-11-10, BEA-2010-11-11, BEA-2010-11-02, and BEA-2010-11-13

- Site Recording Forms for BEA-2010-11-01 and BEA-2010-11-07

- Site Monitoring Forms for previously recorded isolates: 10-BT-1159 and 10-BT-1246

- Site Monitoring Forms for previously recorded sites: 10-BT-1059, 10-BT-1062, 10-BT-1063, 10 -

BM-109, 10-BT-1049, 10-BT-1053, 10-BT-1247, 10-BT-1246, 10-BT-1052, LMIT-1997-16-22, 10 -

BM-118, 10-BM-115, 10-BM-112, and 10-BM-110 
INTENTIONALLY BLANK 
Official Use Only information on pages 65 through 118 removed. 